\title{
52. GEOCHEMISTRY OF BASALTS FROM COSTA RICA RIFT SITES 504 AND 505 (DEEP SEA DRILLING PROJECT LEGS 69 AND 70) ${ }^{1}$
}

\author{
H.-W. Hubberten, ${ }^{2}$ R. Emmermann,${ }^{3}$ and H. Puchelt, Institut für Petrographie und Geochemie, \\ Universität Karlsruhe, Karlsruhe, Federal Republic of Germany
}

\begin{abstract}
We obtained major and trace element data on 113 samples from basalts drilled during DSDP Legs 69 and 70 in the Costa Rica Rift area. The majority have major and trace element characteristics typical of ocean-ridge tholeiities. Most of the basalts are relatively $\mathrm{MgO}$ rich $(\mathrm{MgO}>8 \mathrm{wt} . \%)$ and have $\mathrm{Mg}$ values $(\mathrm{MgO} / \mathrm{MgO}+0.85 \mathrm{FeO} \times 100)$ of about 53 , characteristics that clearly indicate that the various magmas underwent only a small amount of crystal fractionation before being erupted onto the seafloor. According to their normative mineralogies, the rocks are olivine tholeiites. A few samples plot close to the diopside-hypersthene join of the projected basalt tetrahedron.

Except for basalts from two thin intervals in Hole 504B, which differ significantly from all the other basalts of the hole, practically no chemical downhole variation could be established. In the two exceptional intervals, both $\mathrm{TiO}_{2}$ and $\mathrm{P}_{2} \mathrm{O}_{5}$ contents are markedly enriched among the major oxides. The trace elements in these intervals are distinguished by relatively high contents of magmatophile elements and have flat to enriched chondrite-normalized distribution patterns of light rare earth elements (LREE). Most of the rocks outside these intervals are strongly depleted in large-ionlithophile (LIL) elements and LREE. We offer no satisfactory hypothesis for the origin of these basalts at this time. They might have originated within pockets of mantle materials that were more primitive than the LIL-element-depleted magmas that were the source of the other basalts.

A significant change with depth in the type of alteration occurs in the 561 meters of basalt cored in Hole 504B. According to the behavior of such alteration-sensitive species as $\mathrm{K}_{2} \mathrm{O}, \mathrm{H}_{2} \mathrm{O}^{-}, \mathrm{CO}_{2}, \mathrm{~S}, \mathrm{Tl}$, and the iron oxidation ratio, the alteration is oxidative in the upper part and nonoxidative or even reducing in the lower part. The oxidative alteration may have resulted from low temperature basalt/seawater interaction, whereas hydrothermal solutions may be responsible for the nonoxidative alteration.
\end{abstract}

\section{INTRODUCTION}

During Legs 69 and 70 of the Deep Sea Drilling Project, several holes were drilled through sediments and into basalts where heat flow measurements (e.g., CRRUST, 1982) indicated the existence of contrasting geothermal regimes. The holes were south of the Costa Rica Rift (Fig. 1), the easternmost actively spreading segment of the Galapagos Spreading Center (Lonsdale and Klitgord, 1978). Sites with different geothermal characteristics were selected deliberately to permit the study of geothermal phenomena. Site 505 was in an area of low heat flow, and Site 504 was in an area of high heat flow.

Our investigation concentrates primarily on Hole $504 \mathrm{~B}$, which is located at $1^{\circ} 13.63^{\prime} \mathrm{N}, 38^{\circ} 43.8^{\prime} \mathrm{W}$ on crust $5.9 \mathrm{~m} . \mathrm{y}$. old. This hole reached a sub-bottom depth of 836 meters, with a total basement penetration of 561 meters. The basement section cored is made up of a sequence of massive flows (which become more abundant in deeper parts) and pillows or thin basalt flows. Most of the pillow or thin lava flows are highly fractured and allow the intensive circulation of solutions. A downflow of cold seawater at a rate of about $50 \mathrm{gal} . / \mathrm{hr}$. was induced by drilling. The water issued into the base-

\footnotetext{
${ }^{1}$ Cann, J. R., Langseth, M. G., Honnorez, J., Von Herzen, R. P., White, S. M., et al., Init. Repts. DSDP, 69: Washington (U.S. Govt. Printing Office).

2 Present address: Instituto de Geología, Universidad Autónoma de Nuevo Leon, 67700 Linares, N.L., Mexico.

${ }^{3}$ Present address: Mineralogisch-Petrologisches Institut, Universität Giessen, Federal Republic of Germany.
}

ment at a depth of 90 meters below the sediments (CRRUST, 1982).

The basalts recovered exhibit a wide range of textures, from glassy spherulitic in pillows or thin flows to ophitic intergranular in some of the massive lavas. Most of the samples are moderately phyric, with plagioclase and olivine as dominant phenocryst phases. Clinopyroxene phenocrysts are abundant in some units. $\mathrm{Cr}$-spinel occurs in other units in minor amounts. Titanomagnetite is the dominant opaque mineral, and it is often accompanied by primary sulfide spherules. According to the Site 501/504 chapter (this volume), 49 lithologic units were defined in Hole 504B by the shipboard scientific parties on the basis of the distribution of the phenocryst assemblages observed in thin sections and hand specimens.

Alteration is slight to moderate in the massive units and moderate to high in the fractured basalts. A significant downhole change occurs in the type of alteration minerals. Reddish-brown iddingsites and iron oxy-hydroxides are characteristic alteration products in the upper part of the basement (down to $584 \mathrm{~m}$ sub-bottom), indicating oxidative alteration conditions; below this depth they are virtually absent (see Honnorez et al., this volume). Instead, pyrite, which is very rare in the upper part of the hole, becomes abundant. A third type of alteration, in which zeolites are abundant, occurs between 534.5 meters and 543.5 meters and is superimposed on the earlier oxidative alteration. This zone differs from that in the upper and the lower part of the hole in the nature and amount of the secondary minerals, which fill 


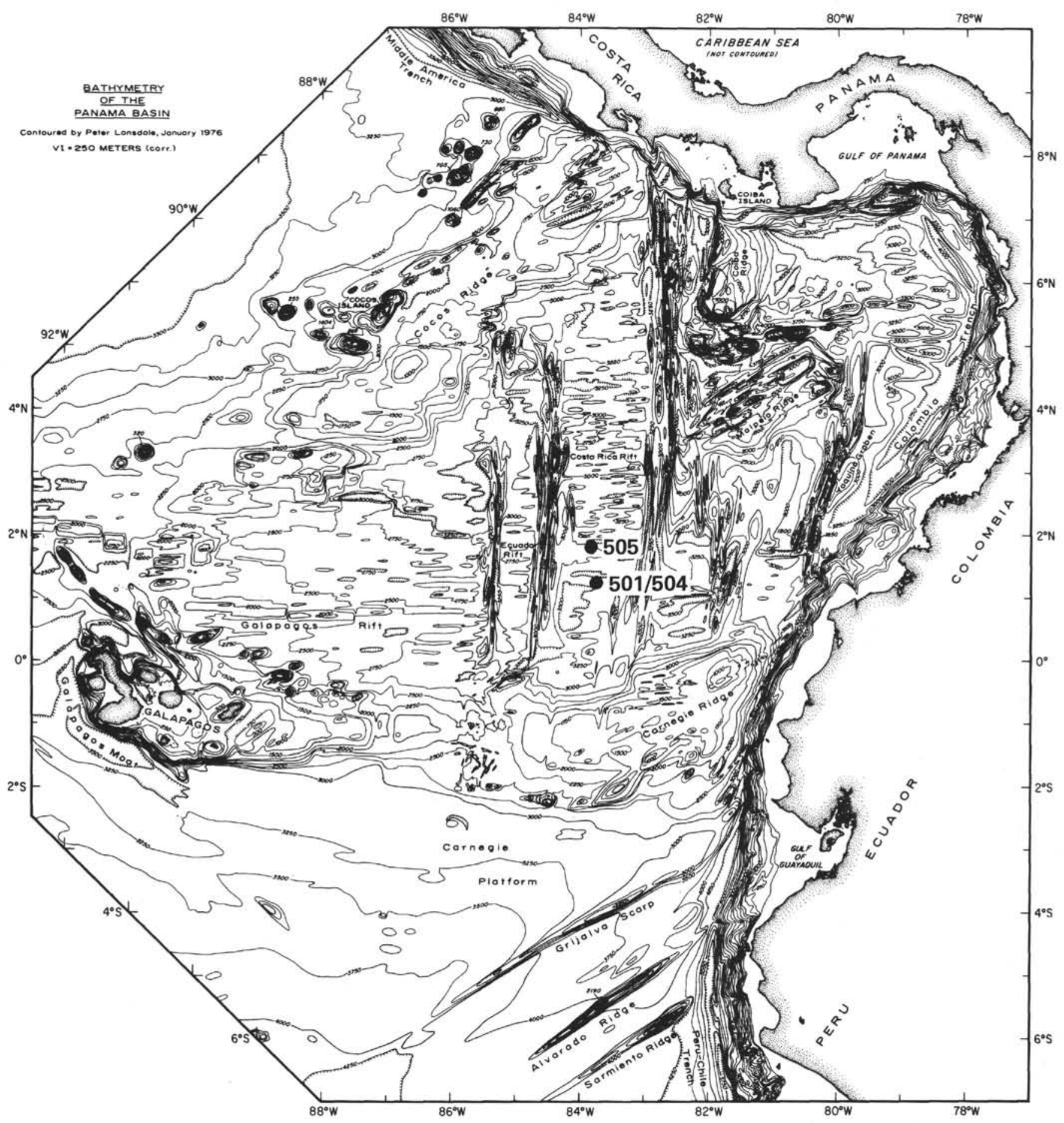

Figure 1. Location of Sites 501, 504, and 505. Bathymetry after Lonsdale and Klitgord (1978). Contour interval is $250 \mathrm{~m}$.

all fractures and seal this part against circulating solutions. For a detailed description of alteration mineralogy see Honnorez et al. (this volume).

The main objective of this chapter is to define the bulk chemical characteristics of the material recovered from Hole 504B. Through detailed geochemical investigations we will try to answer the following questions:

1) What is the chemical composition and variation of the young crustal basalts at the Costa Rica Rift?
2) What conclusions can be reached with respect to their mode of formation?

3) Are there any significant chemical changes that can be related to alteration processes?

\section{ANALYTICAL PROCEDURE}

We selected 68 samples for analysis from the Leg 70 part of Hole 504B while we were on board ship. We also selected 27 samples from the upper part of Hole 504B and from Holes 504A, 505A, and 505B 
that were collected during Leg 69 , to which we added another $18 \mathrm{Leg}$ 69 samples that we chose during the post-cruise meeting at La Jolla. Sample density is such that each lithologic unit is represented by at least one sample. In order to determine the primary compositional variation of the basalts we took care to select the freshest material possible, that is, material devoid of smectite, carbonate, and so forth.

All the samples were renumbered in our laboratory. Table 1 lists the DSDP sample designations and the corresponding laboratory sample numbers. For the sake of brevity we will refer to the laboratory sample numbers in this paper.

After removing alteration rims the samples were cleaned with distilled water, crushed with the help of a pneumatic press, ground with an agate mill to $<200 \mathrm{mesh}$, and dried at $105^{\circ} \mathrm{C}$. All the samples were analyzed for their major components, including $\mathrm{H}_{2} \mathrm{O}^{+}$and $\mathrm{CO}_{2}$; in addition, 23 trace elements were determined on 27 samples. X-ray fluorescence analysis (XRF) was used for the determination of $\mathrm{Si}, \mathrm{Ti}$, $\mathrm{Al}, \mathrm{Fe}, \mathrm{Mn}, \mathrm{Mg}, \mathrm{Ca}, \mathrm{Na}, \mathrm{K}, \mathrm{P}, \mathrm{Zr}, \mathrm{Y}, \mathrm{Sr}, \mathrm{Zn}$, and $\mathrm{Ni}$. The analyses were carried out on fused glass beads of lithium metaborate (rock-toflux ratio: 1:4) by routine XRF techniques using a Philips PW 1450 computerized spectrometer. For concentration calculations the Philips "alphas" program was used.

Instrumental neutron activation analysis (INAA) was used for $\mathrm{Fe}$, $\mathrm{Mn}, \mathrm{Na}, \mathrm{Sc}, \mathrm{Cr}, \mathrm{Co}, \mathrm{Hf}$, and $\mathrm{Ta}$ as well as the REE $\mathrm{La}, \mathrm{Ce}, \mathrm{Nd}, \mathrm{Sm}$, $\mathrm{Eu}, \mathrm{Gd}, \mathrm{Tb}, \mathrm{By}, \mathrm{Yb}$, and $\mathrm{Lu}$. The analytical procedure adopted has been described by Kramar and Puchelt (in press). Atomic absorption spectrometry (AAS), using a Varian AA6 spectrometer, was used to determine $\mathrm{V}, \mathrm{Cr}, \mathrm{Ni}, \mathrm{Cu}$, and $\mathrm{Zn}$. Coulometric titration was used to determine $\mathrm{CO}_{2}$ and S. $\mathrm{H}_{2} \mathrm{O}^{+}$was measured by Karl Fischer titration after thermal decomposition of the rock. Ferrous iron was determined by manganometric titration.

Concentrations of the following elements were below detection limits (detection limit and method used are shown in parentheses): $\mathrm{Rb}$ ( $3 \mathrm{ppm}, \mathrm{XRF}), \mathrm{Nb}$ (3 ppm, XRF), Ba (50 ppm, XRF), Cs (0.7 ppm, INAA), Sb (0.5 ppm, INAA), Th ( $<1 \mathrm{ppm}$, INAA) and U $(<1 \mathrm{ppm}$, INAA). Precision was tested by duplicate measurements of selected samples; accuracy was always checked by carrying the reference rocks BCR-1 and BHVO-1 through the whole procedure along with the basalt samples. The values we obtained for BCR-1 and BHVO-1 are summarized in Table 2 (data from Puchelt and Kramar, 1981 and Kramar and Puchelt, in press).

This table also contains our data for the three samples used as interlaboratory standards; these samples were distributed to all the laboratories that participated in the analysis of Leg 69 and 70 basalts.

\section{MAJOR AND TRACE ELEMENT CHEMISTRY}

Major element analyses of the Hole 504A, 504B, $505 \mathrm{~A}$, and $505 \mathrm{~B}$ basalts along with the normative mineralogies calculated from these data are given in Table 3 . Table 4 presents trace element data for these samples. Table 5 shows the REE and some additional trace elements for 27 samples selected from these holes.

Before the chemical data can be evaluated, it is necessary to determine the extent to which the primary composition of the basalts analyzed has been affected by low temperature seawater interaction or hydrothermal alteration. The experience acquired in many previous investigations of ocean-floor basalts makes it possible to determine the freshness of the basalts from its concentrations of $\mathrm{H}_{2} \mathrm{O}^{+}, \mathrm{CO}_{2}$, and $\mathrm{K}_{2} \mathrm{O}$ and the degree of oxidation (expressed as $\mathrm{Fe}_{2} \mathrm{O}_{3} / \mathrm{FeO}+\mathrm{Fe}_{2} \mathrm{O}_{3}$ ). The following limits can be defined for fresh basaltic material: $\mathrm{H}_{2} \mathrm{O}^{+}<0.5$ wt. $\%, \mathrm{CO}_{2}<0.15$ wt. $\%, \mathrm{~K}_{2} \mathrm{O}<0.25$ wt.\%, and $\mathrm{Fe}^{3+} / \mathrm{Fe}^{2+}<0.15$ (Puchelt and Emmermann, in press). If these freshness criteria are applied to the basalts from Sites 504 and 505, all the samples from Site 504 are more or less altered. The Site 505 basalts represent the freshest samples cored at the Costa Rica Rift.
Thus, the composition of Hole 504B basalts must be discussed with the understanding that practically no fresh material was obtained from this hole.

\section{Alteration-Sensitive Elements}

The subdivision of Hole 504B into an upper and a lower part according to the presence or absence of specific secondary minerals (see Honnorez et al., this volume) is nicely reflected in the significant downhole variations of the degree of oxidation and the concentrations of $\mathrm{K}_{2} \mathrm{O}, \mathrm{Tl}$, and S (Fig. 2). In the upper part of the hole $\mathrm{Fe}^{3+} / \mathrm{Fe}^{2+}$ varies between 0.26 and 0.56 , with an average of 0.41 . Below a sub-bottom depth of 584 meters this ratio is consistently lower (between 0.22 and 0.45 ) and averages 0.31 . This is in accordance with an assumption of nonoxidative or even reducing alteration conditions. The most pronounced changes between the upper and lower parts of the hole are in the concentrations of $\mathrm{K}_{2} \mathrm{O}$ and $\mathrm{Tl}$, both of which are very low and uniform in the lower part of the hole (averaging 0.02 wt. $\%$ and $3.4 \mathrm{ppb}$ respectively) but have considerable scatter and clearly higher values in the oxidized part of the hole $(0.16 \mathrm{wt} . \%$ and $34.1 \mathrm{ppb})$. Since the potassium enrichment of ocean-floor basalts has been proven to be one of the most consistent features of low temperature basalt/seawater interaction (Honnorez, 1980), the $\mathrm{K}_{2} \mathrm{O}$ enrichment of the rocks recovered from the upper alteration zone is a strong argument in favor of the existence of this process. $\mathrm{Tl}$, which geochemically behaves very much like $\mathrm{K}$, seems to be an even more sensitive indicator of low temperature basalt/seawater interaction (McGoldrick et al., 1979), because the absolute concentration changes are much higher (from 1 to $10 \mathrm{ppb}$ with an average of 3.4 in the lower part and from 1 to 201 ppb with an average of 34.1 in the upper part). $\mathrm{CO}_{2}$ shows no significant change from the upper to the lower part of the hole, with mean values of 0.12 and 0.11 wt. \%, respectively.

There are no obvious downhole variations in $\mathrm{H}_{2} \mathrm{O}^{+}$ concentration. The values found are between 0.44 and $1.40 \mathrm{wt} . \%$, and their average is $0.72 \mathrm{wt} . \%$.

\section{Major Oxides}

The downhole variation in the concentration of the major oxides is shown in Figure 3. In general, there are only small compositional fluctuations and no systematic concentration changes with increasing depth. The only notable exceptions to this very uniform picture occur in the concentrations of $\mathrm{TiO}_{2}$ and $\mathrm{P}_{2} \mathrm{O}_{5}$, both of which become significantly enriched in Lithologic Units 5 and 36 , two minor lithologic units at sub-bottom depths from 398.0 to 404.5 meters and from 672.7 to 715.2 meters, respectively. The following ranges of variation were found for the majority of the basalts: $\mathrm{SiO}_{2}, 48.7$ to 50.9 wt.\%; $\mathrm{TiO}_{2}, 0.77$ to 1.14 wt. $\% ; \mathrm{Al}_{2} \mathrm{O}_{3}, 14.1$ to 17.4 wt. \%, $\mathrm{Fe}_{2} \mathrm{O}_{3}, 1.86$ to 5.93 wt. \%; $\mathrm{FeO}, 3.60$ to 7.40 wt. \%; $\mathrm{MnO}, 0.14$ to 0.22 wt. $\%$; $\mathrm{MgO}, 6.67$ to 9.35 wt. \%; $\mathrm{CaO}, 11.2$ to 13.8 wt. \%; $\mathrm{Na}_{2} \mathrm{O}, 1.93$ to 2.69 wt. $\% ; \mathrm{K}_{2} \mathrm{O}, 0.01$ to 0.39 wt. $\% ; \mathrm{P}_{2} \mathrm{O}_{5}, 0.4$ to 0.9 wt. \%. The same ranges also apply to basalts from Lithologic Units 5 and 36, except that $\mathrm{TiO}_{2}$ ranges between 1.27 
Table 1. Correlation of DSDP sample designations and our laboratory sample numbers.

\begin{tabular}{ccc}
\hline \multicolumn{2}{c}{ DSDP Sample Number } & Laboratory \\
$\begin{array}{c}\text { Hole/Core/Section } \\
\text { (interval in cm) }\end{array}$ & $\begin{array}{c}\text { Piece } \\
\text { Number }\end{array}$ & $\begin{array}{c}\text { Sample } \\
\text { Number }\end{array}$ \\
\hline
\end{tabular}

$$
\text { Leg } 69
$$

\begin{tabular}{|c|c|c|}
\hline $504 \mathrm{~A}-6-1,50-52$ & 11 & 5101 \\
\hline $6-1,134-138$ & 25 & 5102 \\
\hline $6-2,88-96$ & 40 & 5103 \\
\hline $7-2,48-52$ & 81 & 5104 \\
\hline $504 \mathrm{~B}-3-1,16-19$ & 241 & 5105 \\
\hline $4-1,33-40$ & 269 & 5106 \\
\hline $5-1,106-109$ & 370 & 5107 \\
\hline $6-2,108-112$ & 423 & 5108 \\
\hline $7-5,63-65$ & 515 & 5109 \\
\hline $8-1,1-2$ & 519 & 5110 \\
\hline $8-2,43-45$ & 528 & 5167 \\
\hline $8-4,120-123$ & 557 & 5111 \\
\hline $9-1,31-33$ & 571 & 5168 \\
\hline $9-2,80-83$ & 597 & $51 \quad 12$ \\
\hline $10-2,12-14$ & 628 & 5113 \\
\hline $11-1,23-25$ & 663 & 5151 \\
\hline $11-2,128-130$ & 693 & 5152 \\
\hline $12-1,42-45$ & 714 & 5153 \\
\hline $13-2,102-103$ & 782 & 5154 \\
\hline $13-2,118-122$ & 785 & 5155 \\
\hline $13-4,22-26$ & 804 & 5156 \\
\hline $13-4,116-122$ & 816 & 5160 \\
\hline $14-1,86-89$ & 848 & 5157 \\
\hline $15-2,130-132$ & 902 & 5158 \\
\hline $15-5,3-5$ & 946 & 5159 \\
\hline $16-2,5-10$ & 975 & 5114 \\
\hline $16-2,110-112$ & 983 & 5161 \\
\hline $17-2,130-137$ & 1069 & 5115 \\
\hline $18-1,110-115$ & 1095 & 5116 \\
\hline $19-1,98-103$ & 1126 & 5117 \\
\hline $19-2,93-95$ & 1146 & 5118 \\
\hline $20-1,48-51$ & 1165 & 5162 \\
\hline $21-1,123-125$ & 1191 & 5163 \\
\hline $21-2,67-70$ & 1209 & 5164 \\
\hline $21-3,111-114$ & 1233 & 5165 \\
\hline $23-1,73-75$ & 1320 & 5119 \\
\hline $25-1,41-44$ & 1403 & 5166 \\
\hline $25-2,36-38$ & 1425 & 5120 \\
\hline $27-1,105-110$ & 1473 & 5121 \\
\hline $28-4,125-130$ & 1553 & 5122 \\
\hline $29-1,50-52$ & 1569 & 5123 \\
\hline
\end{tabular}

Leg 70

\begin{tabular}{lll}
$504 \mathrm{~B}-32-1,81-83$ & 147 & 5301 \\
$33-1,12-14$ & 182 & 5302 \\
$36-1,68-70$ & 299 & 5303 \\
$36-1,91-110$ & 301 & 5304 \\
$36-3,83-85$ & 324 & 5305 \\
$36-4,68-70$ & 332 & 5306 \\
$37-2,94-96$ & 377 & 5307 \\
$38-1,90-92$ & 420 & 5308 \\
$39-1,35-37$ & 460 & 5309 \\
$39-1,106-110$ & 470 & 5310 \\
$39-3,123-125$ & 495 & 5311 \\
$40-2,72-88$ & 532 & 5312 \\
$40-4,73-75$ & 567 & 5313 \\
$41-2,17-19$ & 599 & 5314 \\
$41-3,121-123$ & 626 & 5315 \\
$42-1,9-11$ & 642 & 5316 \\
$42-2,59-61$ & 667 & 5317 \\
$43-1,63-65$ & 679 & 5318 \\
$43-2,44-46$ & 697 & 5319 \\
$44-1,128-130$ & 716 & 5320 \\
$44-1,133-135$ & 717 & 5321 \\
\hline & &
\end{tabular}

Table 1. (Continued).

\begin{tabular}{ccc}
\hline \multicolumn{2}{c}{ DSDP Sample Number } & Laboratory \\
$\begin{array}{c}\text { Hole/Core/Section } \\
\text { (interval in cm) }\end{array}$ & $\begin{array}{c}\text { Piece } \\
\text { Number }\end{array}$ & $\begin{array}{c}\text { Number } \\
\text { Number }\end{array}$ \\
\hline
\end{tabular}

Leg 69

\begin{tabular}{|c|c|c|}
\hline & & \\
\hline $45-1,110-112$ & 746 & 5322 \\
\hline $46-2,129-131$ & 791 & 5323 \\
\hline $46-3,46-48$ & 798 & 5324 \\
\hline $47-1,129-131$ & 820 & 5325 \\
\hline $47-2,143-145$ & 836 & 5327 \\
\hline $47-4,49-51$ & 854 & 5328 \\
\hline $48-1,56-59$ & 865 & 5329 \\
\hline $48-1,24-26$ & 862 & 5330 \\
\hline $48-2,23-25$ & 878 & 5331 \\
\hline $48-2,40-42$ & 880 & 5332 \\
\hline $48-3,23-25$ & 895 & 5333 \\
\hline $49-2,69-73$ & 944 & 5334 \\
\hline $49-2,94-96$ & 947 & 5335 \\
\hline $50-1,32-34$ & 962 & 5336 \\
\hline $51-1,27-29$ & 973 & 5337 \\
\hline $52-1,58-61$ & 995 & 5338 \\
\hline $52-4,91-93$ & 1049 & 5339 \\
\hline $54-1,39-42$ & 1062 & 5340 \\
\hline $54-1,131-135$ & 1071 & 5341 \\
\hline $55-1,36-39$ & 1083 & 5342 \\
\hline $55-2,34-36$ & 1098 & 5343 \\
\hline $56-1,76-79$ & 1108 & 5344 \\
\hline $57-1,14-17$ & 1127 & 5345 \\
\hline $57-3,13-15$ & 1161 & 5346 \\
\hline $58-2,84-89$ & 1215 & 5347 \\
\hline $59-1,57-63$ & 1252 & 5348 \\
\hline $60-1,102-105$ & 1266 & 5349 \\
\hline $61-2,12-15$ & 1299 & 5350 \\
\hline $62-1,105-109$ & 1323 & 5351 \\
\hline $62-2,5-8$ & 1332 & 5352 \\
\hline $63-2,136-140$ & 1374 & 5353 \\
\hline $63-2,96-98$ & 1368 & 5354 \\
\hline $63-4,10-13$ & 1392 & 5355 \\
\hline $63-4,72-77$ & 1399 & 5356 \\
\hline $64-1,119-124$ & 1417 & 5357 \\
\hline $64-2,111-113$ & 1434 & 5358 \\
\hline $64-3,93-98$ & 1451 & 5359 \\
\hline $64-3,105-107$ & 1452 & 5360 \\
\hline $65-1,20-25$ & 1476 & 5361 \\
\hline $66-1,141-145$ & 1505 & 5363 \\
\hline $66-2,115-120$ & 1520 & 5364 \\
\hline $66-2,139-141$ & 1523 & 5362 \\
\hline $67-1,15-18$ & 1525 & 5365 \\
\hline $68-1,102-104$ & 1538 & 5366 \\
\hline $69-1,57-59$ & 1543 & 5367 \\
\hline $69-1,69-73$ & 1544 & 5368 \\
\hline $70-1,96-100$ & 1559 & 5369 \\
\hline $70-2,12-16$ & 1564 & 5370 \\
\hline & & \\
\hline $1-1-1,25-33$ & 102 & 5124 \\
\hline $3-2-1,4-10$ & 112 & 5125 \\
\hline $2-1,119-121$ & 124 & 5126 \\
\hline $2-1,142-147$ & 127 & 5127 \\
\hline
\end{tabular}

and 1.36 wt. $\%$ and $\mathrm{P}_{2} \mathrm{O}_{5}$ ranges between 0.15 and 0.20 wt. $\%$.

\section{Basalt Classification}

The CIPW norm was used for the normative classification of the basalts. To avoid the effects of oxidation, the $\mathrm{Fe}_{2} \mathrm{O}_{3}$ content was fixed at a value of $1.5 \mathrm{wt} . \%$ in the 


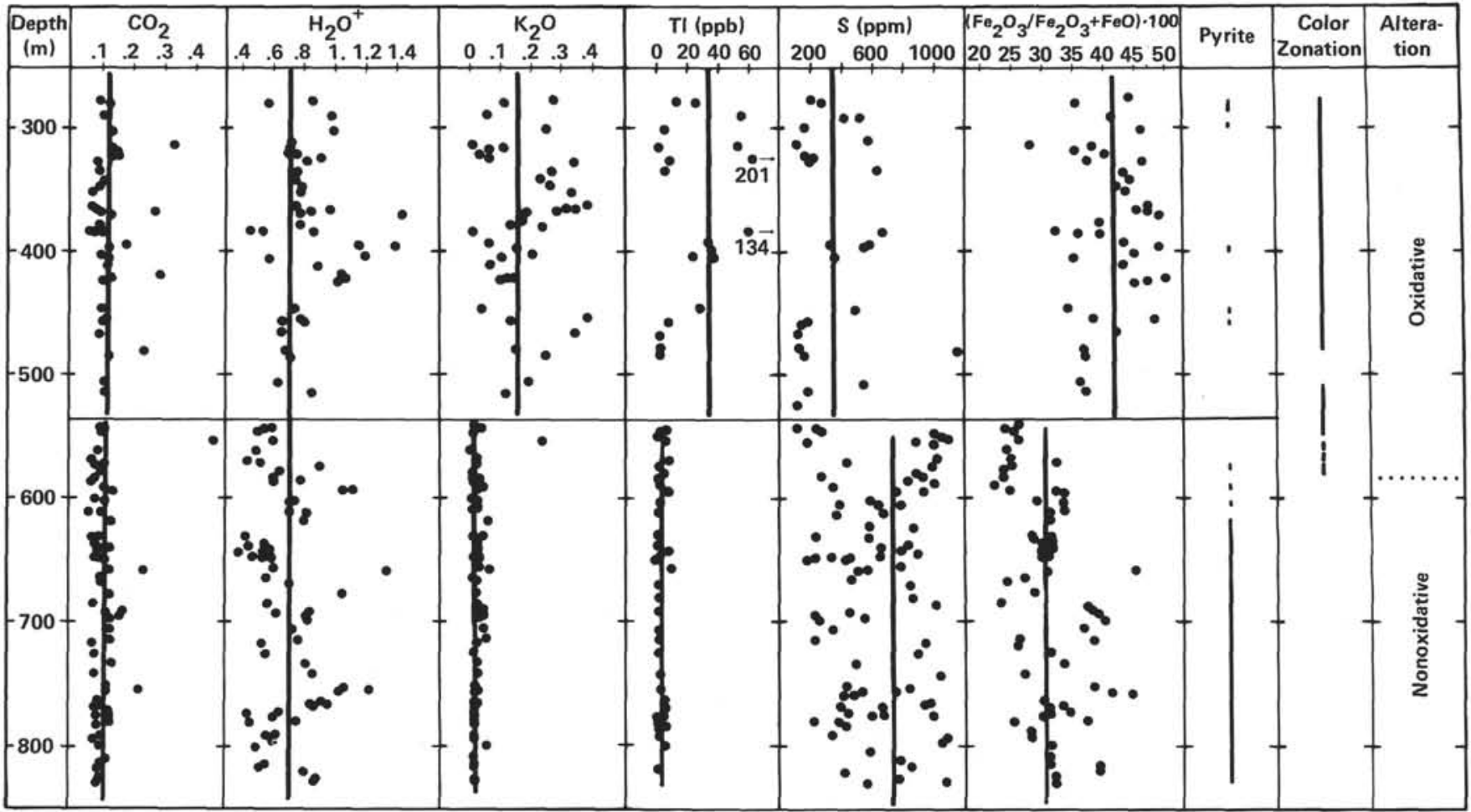

Figure 2. Downhole distribution of components sensitive to alteration of bulk rocks analyzed of "fresh" basalts. Tl data are from Erzinger (1981); S contents are from Hubberten (this volume).

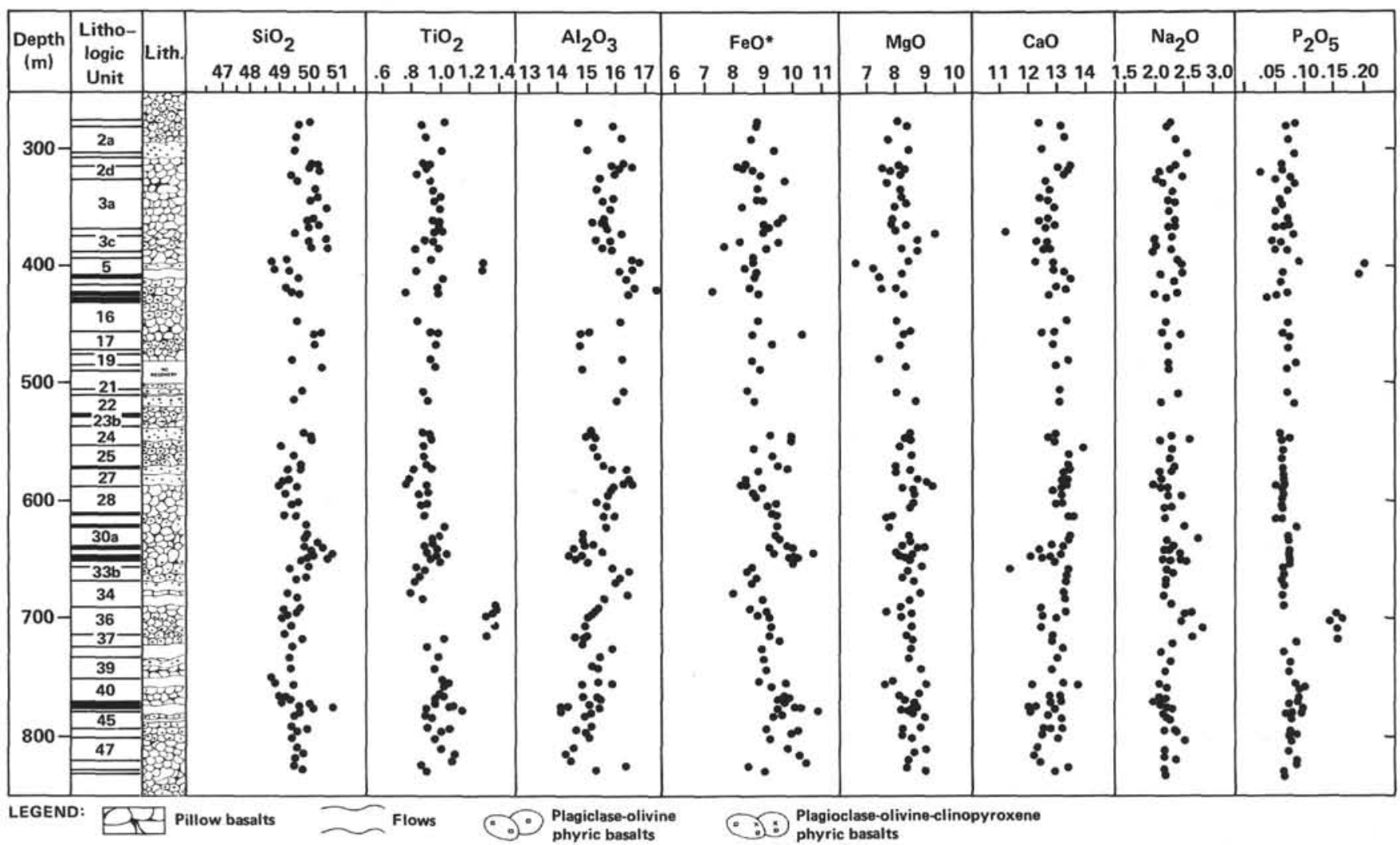

Figure 3. Major element distribution in relation to depth for freshest Hole 504B basalts. 
Table 2. Major and trace element data obtained by our laboratory on BCR-1, ${ }^{\mathrm{a}}$ BHVO- $1,{ }^{\mathrm{b}}$ and the three samples used as interlaboratory standards.

\begin{tabular}{|c|c|c|c|c|c|}
\hline & BCR-1 & BHVO-1 & IC 1 & IC 2 & IC 3 \\
\hline \multicolumn{6}{|c|}{ Major Elements (wt.\%) } \\
\hline $\mathrm{SiO}_{2}$ & 54.3 & 49.8 & 50.1 & 50.0 & 49.0 \\
\hline $\mathrm{TiO}_{2}$ & 2.31 & 2.77 & 0.75 & 0.91 & 0.78 \\
\hline $\mathrm{Al}_{2} \mathrm{O}_{3}$ & 13.6 & 14.08 & 15.5 & 15.0 & 16.2 \\
\hline $\mathrm{Fe}_{2} \mathrm{O}_{3}$ & 3.82 & 3.16 & 1.83 & 2.38 & 1.89 \\
\hline $\mathrm{FeO}$ & 8.63 & 8.10 & 7.01 & 7.25 & 6.64 \\
\hline $\mathrm{CaO}$ & 7.03 & 11.53 & 13.7 & 12.6 & 13.2 \\
\hline $\mathrm{MgO}$ & 3.57 & 7.42 & 8.39 & 8.32 & 8.78 \\
\hline $\mathrm{MnO}$ & 0.19 & 0.17 & 0.16 & 0.17 & 0.15 \\
\hline $\mathrm{Na}_{2} \mathrm{O}$ & 3.33 & 2.26 & 1.99 & 2.31 & 2.09 \\
\hline $\mathrm{K}_{2} \mathrm{O}$ & 1.85 & 0.60 & 0.02 & 0.01 & 0.01 \\
\hline $\mathrm{P}_{2} \mathrm{O}_{5}$ & 0.35 & 0.31 & 0.05 & 0.06 & 0.03 \\
\hline $\mathrm{H}_{2} \mathrm{O}^{+}$ & 0.82 & 0.20 & 0.38 & 0.62 & 0.68 \\
\hline $\mathrm{CO}_{2}$ & $<0.1$ & $<0.1$ & 0.18 & 0.14 & 0.14 \\
\hline \multicolumn{6}{|c|}{ Trace Elements (ppm) } \\
\hline Sc & 31.8 & 31.6 & 42.4 & 46.6 & - \\
\hline V & 400 & 311 & 250 & 291 & 270 \\
\hline $\mathrm{Cr}$ & 13 & 276 & 425 & 377 & 462 \\
\hline Co & 36.5 & 46.7 & 42.8 & 44.1 & 41.4 \\
\hline $\mathrm{Ni}$ & 15 & 118 & 77 & 91 & 131 \\
\hline $\mathrm{Cu}$ & 15 & 144 & 108 & 97 & 86 \\
\hline $\mathrm{Zn}$ & 114 & 120 & 66 & 83 & 67 \\
\hline $\mathrm{Zr}$ & 185 & 170 & 31 & 41 & 35 \\
\hline $\mathbf{Y}$ & n.d. & 25 & 23 & 28 & 27 \\
\hline $\mathrm{Hf}$ & 4.73 & 4.31 & 1.06 & 1.29 & 1.19 \\
\hline $\mathrm{La}$ & 27.3 & 17.4 & 0.87 & 1.15 & 0.78 \\
\hline $\mathrm{Ce}$ & 50.7 & 37.3 & 2.4 & 5.4 & 4.1 \\
\hline $\mathrm{Nd}$ & 29.0 & 24 & 3.08 & 4.07 & 3.34 \\
\hline $\mathrm{Sm}$ & 6.93 & 6.67 & 1.52 & 2.01 & 1.72 \\
\hline $\mathrm{Eu}$ & 1.94 & 2.05 & 0.62 & 0.81 & 0.72 \\
\hline Gd & 5.9 & n.d. & 2.90 & 3.59 & 2.74 \\
\hline $\mathrm{Tb}$ & 1.16 & 0.91 & 0.48 & 0.65 & 0.52 \\
\hline Ho & 1.33 & n.d. & 0.83 & 0.91 & 0.76 \\
\hline $\mathrm{Tm}$ & 0.47 & n.d. & 0.41 & 0.46 & 0.37 \\
\hline $\mathrm{Yb}$ & 3.42 & 2.10 & 2.19 & 2.91 & 2.48 \\
\hline Lu & 0.49 & - & 0.32 & 0.46 & 0.37 \\
\hline
\end{tabular}

a Kramar and Puchelt, in press.

b Puchelt and Kramar, 1981.

norm calculations, so normative magnetite always has a value of 2.18. As shown in Figure 4, most of the basalts have normative olivine and plot in the olivine-tholeiite field of the olivine-diopside-hypersthene-quartz tetrahedron, with only a few samples lying on the hypersthene-diopside join.

\section{Trace Elements}

The differences between the Lithologic Unit 5 and 36 basalts and all the other basalts in Hole 504B are even more pronounced in terms of their trace elements (Tables 4 and 5). The differences are particularly pronounced for $\mathrm{Zr}, \mathrm{Hf}, \mathrm{Ta}$, and the light rare earth elements. The basalts from Lithologic Units 5 and 36 (Samples 5116 and 5340 in Tables 4 and 5) display values of $\mathrm{Zr}$, Hf, and $\mathrm{Ta}$ of 101 and $107 \mathrm{ppm}, 2.2$ and $2.6 \mathrm{ppm}$, and 0.73 and $0.13 \mathrm{ppm}$, respectively. The values of $\mathrm{Zr}, \mathrm{Hf}$, and Ta for all the other basalts range from 32 to $66 \mathrm{ppm}, 1.2$ to $1.6 \mathrm{ppm}$, and 0.02 to $0.23 \mathrm{ppm}$, respectively. Most of the basalts from Hole 504B exhibit very similar chondrite-normalized REE patterns (Masuda, 1975), as shown in Figure 5A. These REE patterns are typical for mid-

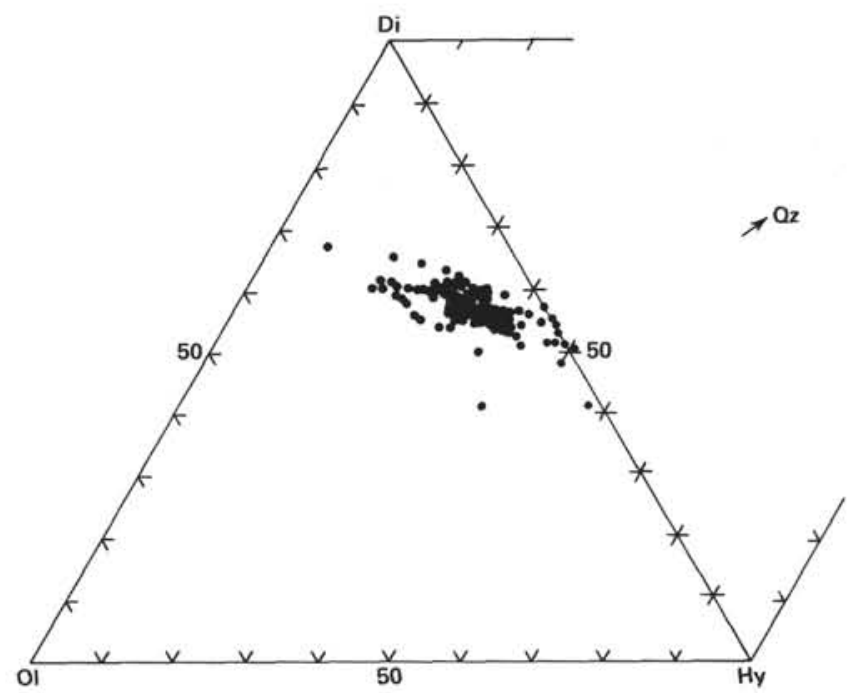

Figure 4. Olivine-diopside-hypersthene-quartz diagram for "fresh" basalts from Sites 504 and 505. For the norm calculations $\mathrm{Fe}_{2} \mathrm{O}_{3}$ was fixed at a value of $1.5 \mathrm{wt} . \%$.

ocean-ridge basalts (MORB) and show a depletion of the light $\mathrm{REE}$ with a $\mathrm{La} / \mathrm{Sm}_{\mathrm{N}}$ ratio (chrondrite normalized) below 0.43 and almost unfractionated heavy REE with $\mathrm{Yb}_{\mathrm{N}}$ values between 12.8 and 18.0.

In contrast, the basalts from Lithologic Units 5 and 36 are only slightly LREE depleted or are even enriched, with $\mathrm{La} / \mathrm{Sm}_{\mathrm{N}}$ ratios of 1.52 and 0.64 , respectively (Fig. $5 \mathrm{~B})$. In addition to these basalts, Sample 5105 , which has "normal" major and trace element contents, has a $\mathrm{La} / \mathrm{Sm}_{\mathrm{N}}$ ratio above unity (1.03). No difference exists in the content of the HREE of these samples when compared with the "normal" Costa Rica Rift basalts.

\section{DISCUSSION}

From the large number of chemical analyses available three main points emerge:

1) The concentrations of some alteration-sensitive elements and the degree of iron oxidation allow a distinction to be made between two significantly different alteration zones. This is in accordance with mineralogical observations (see Honnorez et al., this volume).

2) The primary composition of the basement section drilled is remarkably uniform.

3) Two subordinate lava flows, Lithologic Units 5 and 36 , have exceptional chemistry.

According to their $\mathrm{H}_{2} \mathrm{O}^{+}$contents all the "fresh" basalts analyzed are more or less altered. The concentrations found for $\mathrm{H}_{2} \mathrm{O}^{+}$range between 0.44 and 1.40 wt. $\%$, with most samples close to 0.7 wt. $\% . \mathrm{H}_{2} \mathrm{O}^{+}$determinations on fresh basalt glasses dredged at different localities on the East Pacific Rise and the Galapagos Spreading Center revealed that the water content of fresh ocean-floor tholeiites is below $0.5 \mathrm{wt} . \%$, depending on the degree of fractionation of the magmas (Puchelt and Emmermann, in press). Thus, at least part of the water content is due to alteration. The extent of this type of alteration seems to be mainly a function of the permeability of the basalts (massive versus fractured or pillowed sequences) rather than of depth. 

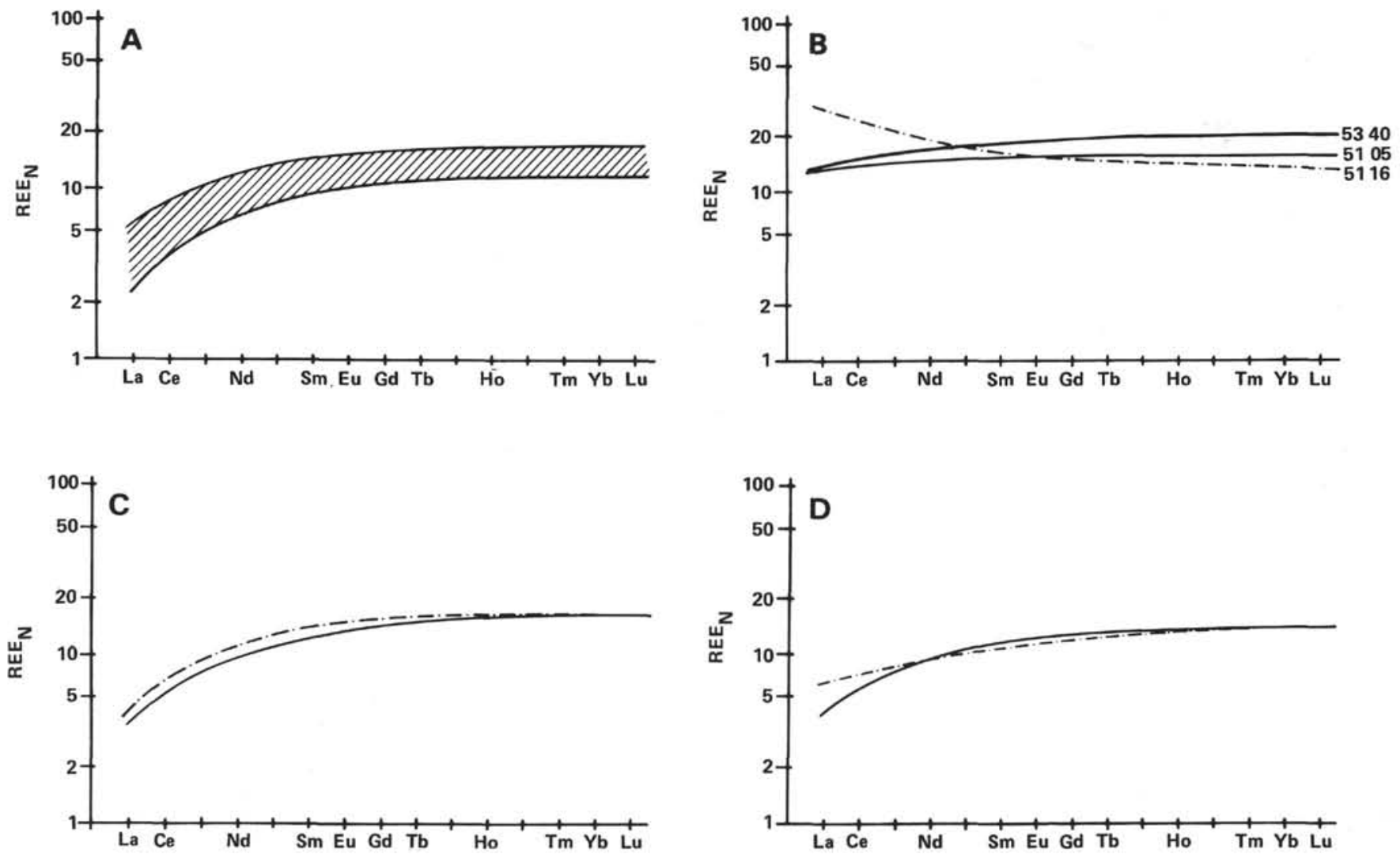

Figure 5. Chondrite-normalized REE patterns. A. Range of "normal" Hole 504B basalts. B. Samples 51 05, 51 16, and 53 40. C. Hole 504A basalts. D. Hole 505A and 505B basalts.

The $\mathrm{CO}_{2}$ concentrations of the freshest possible rocks show a broader scatter in the upper part of the hole, but they do not decrease with depth.

The most pronounced differences between basalts from the upper and lower part of the hole have to do with the degree of iron oxidation and the concentrations of potassium, thallium, and sulfur (Fig. 2). All together, these four indicators of alteration allow a clear distinction to be made between two markedly different types of alteration. One is characterized by low sulfur contents, a high iron oxidation ratio, and potassium as well as thallium enrichment, and the other is not depleted in sulfur, has a low iron oxidation ratio, and is very low in $\mathrm{K}$ and $\mathrm{Tl}$. The first alteration type prevails in the upper part of the basement section (down to a sub-bottom depth of $544.5 \mathrm{~m}$ ), and the second occurs only in the lower part of the hole (below a sub-bottom depth of $544.5 \mathrm{~m}$ ). According to shipboard visual observations of the cores, the last red halo indicating oxidative conditions of alteration (see Honnorez et al., this volume) occurs in Sample 504B-40-3 (130-135 cm), which is from a sub-bottom depth of $584.5 \mathrm{~m}$. There is therefore a transitional zone in the hole $\mathbf{4 0}$ meters thick where the alteration mineralogy indicates that the rocks were oxidatively altered although the bulk rock chemistry is characteristic of suboxic or anoxic alteration.

Apart from these significant downhole variations, which are clearly produced by alteration processes and overprint the primary composition of the rocks to a cer- tain extent, no systematic concentration changes with depth were found in either the major or the trace elements. On the other hand, this result indicates that at least as a first approximation, none of the other components analyzed were affected in terms of concentration by secondary processes in the so-called "fresh" basalts (Fig. 3).

This small degree of variation constitutes a strong argument that the single lava eruptions that built up this basement section were rather uniform in composition and are related by systematic variations in composition, a hypothesis also supported by Figures 6 and 7, which show variation diagrams for $\mathrm{FeO}^{+}$and $\mathrm{Al}_{2} \mathrm{O}_{3}$ with respect to $\mathrm{TiO}_{2}$. Except for Lithologic Units 5 and 36, which differ chemically from all other basement rocks recovered, the basalts analyzed represent typical (i.e., LIL-depleted, $\mathrm{MgO}$-rich, and $\mathrm{K}_{2} \mathrm{O}$-poor) mid-oceanridge tholeiites.

According to their $\mathrm{MgO}$ contents and their $\mathrm{Mg}$ values, which average 52.6, these rocks were generated from rather primitive, (i.e., unevolved) basaltic liquids, which had only undergone a small degree of crystal fractionation prior to being erupted. Because of their relatively high $\mathrm{Mg}$ and $\mathrm{Ca}$ and rather low $\mathrm{Ti}$ and $\mathrm{Fe}$ contents, the basalts from Hole 504B can be regarded as less fractionated than other basalts from the Galapagos spreading system (Anderson et al., 1975; Byerly et al., 1976; Melson et al., 1977; Emmermann et al., in press). The relatively narrow fluctuations in composition, most of 
Table 3. Major element contents and CIPW norms for all investigated samples of "freshest" basalts.

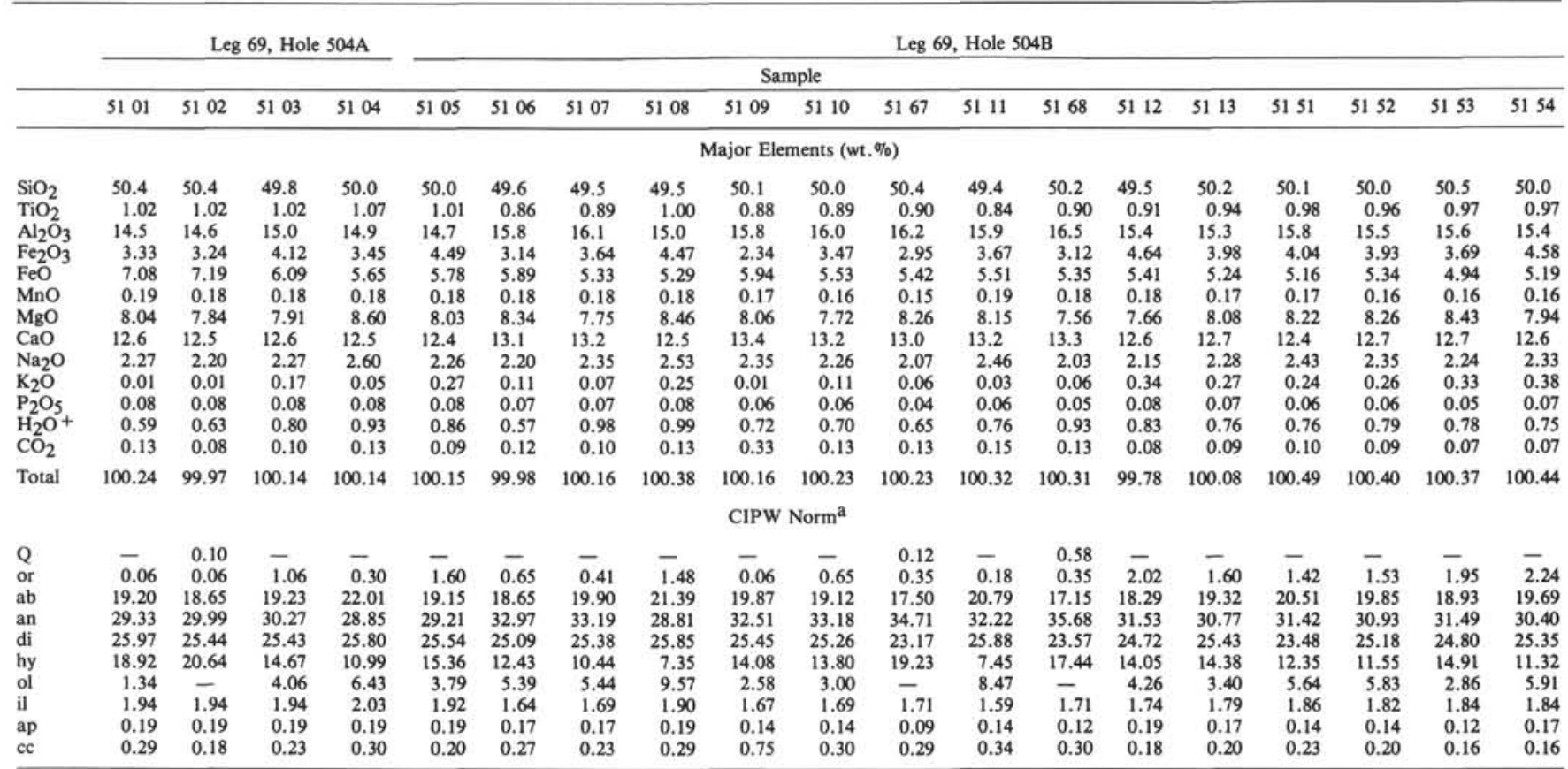

a Normative magnetite (mt), which was always a value of 2.18 because $\mathrm{Fe}_{2} \mathrm{O}_{3}$ was fixed at a value of $1.5 \%$ for the normal calculations, was omitted from the table.

Table 3. (Continued).

\begin{tabular}{|c|c|c|c|c|c|c|c|c|c|c|c|c|c|c|c|c|c|c|c|}
\hline & \multicolumn{2}{|c|}{$\begin{array}{c}\text { Leg 69, } \\
\text { Hole 504B }\end{array}$} & \multicolumn{17}{|c|}{ Leg 70 , Hole 504B } \\
\hline & & & \multicolumn{17}{|c|}{ Sample } \\
\hline & 5122 & 5123 & 5301 & 5302 & 5303 & 5304 & 5305 & 5307 & 5308 & 5309 & 5310 & 5311 & 5312 & 5313 & 5314 & 5315 & 5316 & 5317 & 5318 \\
\hline & \multicolumn{19}{|c|}{ Major Elements (wt.\%) } \\
\hline $\mathrm{SiO}_{2}$ & 49.4 & 50.4 & 48.8 & 49.5 & 49.9 & 50.1 & 50.1 & 49.1 & 49.5 & 49.7 & 49.7 & 49.3 & 49.3 & 49.1 & 49.1 & 49.6 & 49.2 & 49.2 & 49.6 \\
\hline $\mathrm{TiO}_{2}$ & 0.92 & 0.95 & 0.89 & 0.91 & 0.89 & 0.91 & 0.92 & 0.88 & 0.87 & 0.90 & 0.93 & 0.81 & 0.78 & 0.77 & 0.78 & 0.90 & 0.91 & 0.85 & 0.88 \\
\hline $\mathrm{Al}_{2} \mathrm{O}_{3}$ & 16.1 & 14.8 & 16.2 & 16.0 & 15.1 & 15.0 & 15.2 & 15.2 & 15.3 & 15.5 & 15.8 & 16.3 & 16.4 & 16.5 & 16.2 & 15.9 & 15.7 & 15.7 & 15.3 \\
\hline $\mathrm{Fe}_{2} \mathrm{O}_{3}$ & 3.49 & 3.53 & 3.22 & 3.32 & 2.43 & 2.28 & 2.46 & 2.56 & 2.48 & 2.47 & 2.94 & 2.20 & 2.02 & 1.94 & 1.86 & 2.47 & 3.13 & 3.25 & 2.80 \\
\hline $\mathrm{FeO}$ & 5.49 & 5.66 & 5.63 & 5.74 & 7.04 & 7.33 & 7.24 & 6.36 & 7.11 & 7.31 & 6.12 & 6.49 & 6.57 & 6.52 & 6.73 & 6.64 & 5.74 & 5.74 & 6.84 \\
\hline $\mathrm{MnO}$ & 0.18 & 0.19 & 0.17 & 0.16 & 0.16 & 0.16 & 0.16 & 0.16 & 0.17 & 0.17 & 0.17 & 0.15 & 0.15 & 0.14 & 0.15 & 0.15 & 0.17 & 0.15 & 0.15 \\
\hline $\mathrm{MgO}$ & 7.40 & 8.28 & 7.94 & 8.58 & 8.45 & 8.30 & 8.40 & 8.10 & 8.45 & 7.97 & 7.95 & 8.44 & 8.71 & 9.09 & 9.00 & 8.21 & 8.54 & 8.54 & 8.51 \\
\hline $\mathrm{CaO}$ & 13.3 & 12.9 & 13.0 & 13.0 & 12.9 & 12.7 & 12.8 & 13.8 & 13.3 & 13.3 & 13.3 & 13.2 & 13.3 & 13.2 & 13.1 & 13.1 & 12.8 & 13.0 & 12.9 \\
\hline $\mathrm{Na}_{2} \mathrm{O}$ & 2.20 & 2.19 & 2,37 & 2.13 & 2.25 & 2.58 & 2.11 & 2.27 & 2.24 & 2.30 & 2.28 & 2.05 & 2.06 & 1.96 & 2.12 & 2.14 & 2.40 & 2.18 & 2.25 \\
\hline $\mathrm{K}_{2} \mathrm{O}$ & 0.15 & 0.24 & 0.19 & 0.11 & 0.01 & 0.03 & 0.01 & 0.23 & 0.01 & 0.02 & 0.02 & 0.02 & 0.01 & 0.01 & 0.03 & 0.01 & 0.04 & 0.02 & 0.01 \\
\hline $\mathrm{P}_{2} \mathrm{O}_{5}$ & 0.08 & 0.07 & 0.07 & 0.08 & 0.06 & 0.07 & 0.06 & 0.06 & 0.06 & 0.06 & 0.06 & 0.06 & 0.06 & 0.05 & 0.06 & 0.06 & 0.06 & 0.06 & 0.06 \\
\hline $\mathrm{H}_{2} \mathrm{O}^{+}$ & 0.70 & 0.72 & 0.63 & 0.86 & 0.60 & 0.55 & 0.51 & 0.61 & 0.49 & 0.44 & 0.63 & 0.91 & 0.66 & 0.77 & 0.79 & 0.61 & 1.12 & 1.06 & 0.75 \\
\hline $\mathrm{CO}_{2}$ & 0.23 & 0.12 & 0.11 & 0.11 & 0.10 & 0.11 & 0.10 & 0.46 & 0.09 & 0.07 & 0.11 & 0.08 & 0.10 & 0.08 & 0.07 & 0.07 & 0.11 & 0.14 & 0.08 \\
\hline \multirow[t]{2}{*}{ Total } & 99.64 & 100.05 & 100.22 & 100.49 & 99.89 & 100.12 & 100.07 & 99.79 & 100.07 & 100.21 & 100.01 & 100.01 & 100.12 & 100.07 & 99.99 & 99.86 & 99.92 & 99.89 & 100.13 \\
\hline & \multicolumn{19}{|c|}{ CIPW Norma } \\
\hline Q & - & - & - & - & - & - & - & - & - & - & - & - & - & - & - & - & - & - & - \\
\hline or & 0.89 & 1.42 & 1.12 & 0.65 & 0.06 & 0.18 & 0.06 & 1.36 & 0.06 & 0.12 & 0.12 & 0.12 & 0.06 & 0.06 & 0.18 & 0.06 & 0.24 & 0.12 & 0.06 \\
\hline$a b$ & 18.72 & 18.56 & 20.05 & 17.97 & 19.08 & 21.82 & 17.86 & 19.27 & 18.96 & 19.44 & 19.32 & 17.36 & 17.42 & 16.58 & 17.95 & 18.15 & 20.36 & 18.50 & 19.04 \\
\hline an & 33.80 & 29.89 & 32.99 & 33.67 & 31.14 & 29.25 & 31.98 & 30.70 & 31.67 & 31.87 & 32.86 & 35.24 & 35.45 & 36.18 & 34.61 & 33.83 & 32.03 & 33.09 & 31.62 \\
\hline $\mathrm{di}$ & 24.87 & 26.78 & 24.61 & 23.84 & 25.98 & 26.51 & 24.83 & 28.14 & 27.14 & 27.07 & 26.09 & 23.81 & 23.84 & 22.98 & 23.91 & 24.75 & 24.74 & 24.57 & 25.60 \\
\hline hy & 13.48 & 16.23 & 10.33 & 13.17 & 14.58 & 10.25 & 18.38 & 7.51 & 10.44 & 10.61 & 12.19 & 13.93 & 12.63 & 9.04 & 10.83 & 14.58 & 9.44 & 12.83 & 12.74 \\
\hline ol & 2.88 & 1.98 & 5.99 & 5.52 & 4.32 & 7.13 & 2.10 & 7.36 & 7.07 & 6.27 & 4.45 & 4.60 & 5.92 & 6.34 & 7.77 & 3.83 & 7.78 & 5.58 & 6.03 \\
\hline il & 1.76 & 1.81 & 1.68 & 1.72 & 1.69 & 1.73 & 1.75 & 1.68 & 1.65 & 1.71 & 1.77 & 1.54 & 1.48 & 1.46 & 1.48 & 1.71 & 1.73 & 1.62 & 1.67 \\
\hline ap & 0.19 & 0.17 & 0.17 & 0.19 & 0.14 & 0.17 & 0.14 & 0.14 & 0.14 & 0.14 & 0.14 & 0.14 & 0.14 & 0.12 & 0.14 & 0.14 & 0.14 & 0.14 & 0.14 \\
\hline$c$ & 0.53 & 0.27 & 0.25 & 0.25 & 0.23 & 0.25 & 0.23 & 1.05 & 0.20 & 0.16 & 0.25 & 0.18 & 0.23 & 0.18 & 0.16 & 0.16 & 0.25 & 0.32 & 0.18 \\
\hline
\end{tabular}

which coincide with lithostratigraphic boundaries, can plausibly be interpreted as the result of slightly different degrees of fractionation. The very limited extent of crystal fractionation is also apparent in the AFM diagram (Fig. 8), which shows a point cluster rather than any obvious trend.

The occurrence of two chemically exceptional lava flows, Lithologic Units 5 and 36, within this rather uni- form basement sequence poses a major problem. According to their $\mathrm{Mg}$ values these basalts display the same degree of fractionation as all the other rocks recovered. No differences exist between these basalts and those in the rest of the hole with respect to any of their major components except for $\mathrm{Ti}$ and $\mathrm{P}$, which are markedly enriched (see Fig. 9). They are furthermore characteristically enriched in magmatophile trace elements, such 
Table 3. (Continued).

\begin{tabular}{|c|c|c|c|c|c|c|c|c|c|c|c|c|c|c|c|c|c|c|c|}
\hline \multicolumn{20}{|c|}{ Leg 69 , Hole 504B } \\
\hline \multicolumn{20}{|c|}{ Sample } \\
\hline 5155 & 5156 & 5160 & 5157 & 5158 & 5159 & 5114 & 5161 & 5115 & 5116 & 5117 & 5118 & 5162 & 5163 & 5164 & 5165 & 5119 & 5166 & 5120 & 5121 \\
\hline \multicolumn{20}{|c|}{ Major Elements (wt.\%) } \\
\hline 49.8 & 50.1 & 49.9 & 49.3 & 50.5 & 49.9 & 50.6 & 50.1 & 49.2 & 48.7 & 48.8 & 49.5 & 49.6 & 49.3 & 49.3 & 49.6 & 49.6 & 49.7 & 50.4 & 50.2 \\
\hline 0.97 & 0.97 & 0.94 & 0.95 & 0.89 & 0.87 & 0.97 & 1.00 & 0.93 & 1.28 & 1.27 & 0.83 & 1.00 & 0.98 & 0.75 & 0.98 & 0.84 & 0.95 & 0.95 & 0.96 \\
\hline 15.4 & 15.5 & 15.6 & 16.1 & 15.6 & 15.2 & 15.8 & 15.6 & 16.5 & 16.7 & 16.5 & 16.1 & 16.3 & 16.6 & 17.4 & 15.8 & 16.1 & 14.7 & 15.0 & 14.7 \\
\hline 5.65 & 4.29 & 4.44 & 4.56 & 3.18 & 3.09 & 2.91 & 3.64 & 3.62 & 4.41 & 3.92 & 3.15 & 3.85 & 4.56 & 3.78 & 4.12 & 3.13 & 5.14 & 3.45 & 4.01 \\
\hline 4.44 & 5.15 & 5.03 & 4.80 & 5.27 & 6.69 & 5.08 & 5.79 & 4.88 & 4.64 & 4.79 & 5.87 & 5.18 & 4.47 & 4.32 & 5.11 & 5.93 & 5.62 & 5.50 & 5.63 \\
\hline 0.15 & 0.18 & 0.17 & 0.14 & 0.15 & 0.20 & 0.18 & 0.17 & 0.17 & 0.18 & 0.21 & 0.19 & 0.20 & 0.17 & 0.14 & 0.21 & 0.18 & 0.18 & 0.16 & 0.18 \\
\hline 7.88 & 8.15 & 7.97 & 9.35 & 8.74 & 8.69 & 8.70 & 8.20 & 8.42 & 6.67 & 7.21 & 8.20 & 7.40 & 7.50 & 7.99 & 8.09 & 8.02 & 8.27 & 8.41 & 8.12 \\
\hline 12.3 & 12.8 & 12.7 & 11.2 & 12.9 & 13.1 & 12.5 & 13.1 & 12.2 & 12.8 & 12.8 & 13.2 & 13.4 & 12.9 & 13.3 & 13.2 & 13.2 & 12.4 & 12.8 & 12.8 \\
\hline 2.33 & 2.25 & 2.23 & 2.28 & 2.01 & 2.00 & 2.27 & 1.93 & 2.34 & 2.43 & 2.45 & 2.10 & 2.29 & 2.36 & 2.00 & 2.15 & 2.15 & 2.12 & 2.41 & 2.22 \\
\hline 0.34 & 0.28 & 0.24 & 0.18 & 0.17 & 0.12 & 0.01 & 0.24 & 0.06 & 0.15 & 0.20 & 0.10 & 0.07 & 0.14 & 0.13 & 0.10 & 0.04 & 0.39 & 0.13 & 0.34 \\
\hline 0.07 & 0.06 & 0.05 & 0.08 & 0.04 & 0.06 & 0.07 & 0.05 & 0.09 & 0.20 & 0.19 & 0.06 & 0.06 & 0.07 & 0.04 & 0.06 & 0.07 & 0.06 & 0.07 & 0.07 \\
\hline 0.98 & 0.78 & 0.83 & 1.44 & 0.79 & 0.46 & 0.87 & 0.53 & 1.16 & 1.40 & 1.20 & 0.58 & 0.90 & 1.05 & 1.07 & 1.02 & 0.73 & 0.80 & 0.67 & 0.63 \\
\hline 0.08 & 0.09 & 0.27 & 0.13 & 0.09 & 0.06 & 0.10 & 0.06 & 0.18 & 0.12 & 0.10 & 0.12 & 0.12 & 0.29 & 0.13 & 0.10 & 0.10 & 0.10 & 0.10 & 0.09 \\
\hline 100.39 & 100.60 & 100.37 & 100.51 & 100.33 & 100.44 & 100.06 & 100.41 & 99.75 & 99.68 & 99.64 & 100.00 & 100.37 & 100.39 & 100.35 & 100.54 & 100.09 & 100.23 & 100.05 & 99.85 \\
\hline \multicolumn{20}{|c|}{ CIPW Norma } \\
\hline- & - & - & - & - & - & - & - & - & - & - & - & - & - & - & - & - & - & - & - \\
\hline 2.01 & 1.65 & 1.42 & 1.06 & 1.00 & 0.71 & 0.06 & 1.42 & 0.36 & 0.89 & 1.18 & 0.59 & 0.41 & 0.83 & 0.77 & 0.59 & 0.24 & 2.30 & 0.77 & 2.00 \\
\hline 19.72 & 18.98 & 18.86 & 19.25 & 16.98 & 16.88 & 19.22 & 16.30 & 19.89 & 20.69 & 20.64 & 17.80 & 19.35 & 19.95 & 16.90 & 18.14 & 18.21 & 17.93 & 20.42 & 18.69 \\
\hline 30.56 & 31.27 & 31.82 & 33.10 & 32.99 & 32.05 & 32.92 & 33.13 & 34.50 & 34.43 & 33.28 & 34.26 & 33.94 & 34.26 & 38.07 & 33.07 & 34.19 & 29.42 & 29.77 & 29.00 \\
\hline 24.06 & 25.25 & 23.67 & 17.00 & 24.30 & 26.01 & 22.61 & 25.21 & 19.87 & 22.31 & 22.91 & 24.50 & 25.46 & 22.27 & 21.63 & 25.35 & 24.58 & 25.34 & 26.53 & 27.08 \\
\hline 12.85 & 13.10 & 15.52 & 16.86 & 19.25 & 15.31 & 19.81 & 17.52 & 14.73 & 11.37 & 7.90 & 13.51 & 11.68 & 12.13 & 14.17 & 13.35 & 14.07 & 13.98 & 13.58 & 12.84 \\
\hline 5.45 & 4.62 & 3.20 & 6.83 & 0.54 & 4.49 & 0.10 & 1.57 & 4.92 & 3.53 & 7.67 & 4.58 & 3.77 & 4.65 & 3.41 & 4.08 & 3.83 & 5.87 & 3.89 & 5.40 \\
\hline 1.84 & 1.84 & 1.78 & 1.80 & 1.69 & 1.65 & 1.84 & 1.90 & 1.77 & 2.45 & 2.40 & 1.58 & 1.90 & 1.86 & 1.42 & 1.86 & 1.60 & 1.80 & 1.81 & 1.81 \\
\hline 0.17 & 0.14 & 0.12 & 0.19 & 0.09 & 0.14 & 0.17 & 0.12 & 0.21 & 0.48 & 0.45 & 0.14 & 0.14 & 0.17 & 0.09 & 0.14 & 0.17 & 0.14 & 0.17 & 0.16 \\
\hline 0.18 & 0.20 & 0.61 & 0.30 & 0.20 & 0.14 & 0.23 & 0.14 & 0.41 & 0.27 & 0.23 & 0.27 & 0.27 & 0.66 & 0.29 & 0.23 & 0.23 & 0.23 & 0.23 & 0.20 \\
\hline
\end{tabular}

Table 3. (Continued).

\begin{tabular}{|c|c|c|c|c|c|c|c|c|c|c|c|c|c|c|c|c|c|c|c|}
\hline \multicolumn{20}{|c|}{ Leg 70, Hole 504B } \\
\hline \multicolumn{20}{|c|}{ Sample } \\
\hline 5319 & 5320 & 5321 & 5322 & 5323 & 5325 & 5326 & 5328 & 5329 & 5330 & 5331 & 5332 & 5333 & 5334 & 5335 & 5336 & 5337 & 5338 & 5339 & 5340 \\
\hline \multicolumn{20}{|c|}{ Major Elements (wt. \%) } \\
\hline 49.4 & 49.2 & 49.6 & 49.9 & 49.9 & 50.4 & 49.9 & 50.1 & 50.1 & 50.8 & 50.0 & 50.7 & 49.8 & 50.0 & 49.4 & 49.9 & 49.6 & 49.3 & 49.6 & 49.7 \\
\hline 0.87 & 0.88 & 0.87 & 1.12 & 0.95 & 0.94 & 0.89 & 0.89 & 0.97 & 1.03 & 0.96 & 0.96 & 0.99 & 0.83 & 0.84 & 0.86 & 0.83 & 0.80 & 0.88 & 1.36 \\
\hline 15.6 & 15.8 & 15.6 & 15.6 & 14.8 & 14.9 & 15.2 & 15.4 & 14.7 & 14.3 & 14.7 & 14.5 & 15.0 & 15.8 & 16.2 & 16.0 & 15.9 & 16.3 & 15.5 & 15.3 \\
\hline 3.09 & 3.19 & 3.04 & 3.02 & 2.72 & 2.64 & 2.74 & 2.58 & 3.38 & 3.21 & 3.08 & 3.18 & 3.18 & 4.01 & 2.94 & 2.41 & 2.08 & 2.50 & 2.14 & 3.22 \\
\hline 6.27 & 6.36 & 6.61 & 6.73 & 7.00 & 7.40 & 6.69 & 7.01 & 7.00 & 7.70 & 7.32 & 7.00 & 7.04 & 4.98 & 5.84 & 6.53 & 6.69 & 5.67 & 7.03 & 5.58 \\
\hline 0.16 & 0.17 & 0.17 & 0.17 & 0.18 & 0.17 & 0.17 & 0.16 & 0.17 & 0.18 & 0.17 & 0.16 & 0.18 & 0.14 & 0.16 & 0.16 & 0.16 & 0.15 & 0.16 & 0.18 \\
\hline 8.45 & 7.80 & 7.67 & 7.72 & 8.40 & 8.13 & 8.86 & 7.98 & 8.45 & 8.06 & 8.41 & 8.25 & 8.43 & 8.81 & 8.22 & 8.21 & 8.57 & 8.74 & 8.43 & 8.15 \\
\hline 13.1 & 13.3 & 13.5 & 12.0 & 13.3 & 12.7 & 13.1 & 13.0 & 12.6 & 12.4 & 12.8 & 12.4 & 12.8 & 11.3 & 13.3 & 13.2 & 13.2 & 13.1 & 13.2 & 12.4 \\
\hline 2.15 & 2.20 & 2.17 & 2.47 & 2.69 & 2.28 & 2.14 & 2.41 & 2.21 & 2.41 & 2.09 & 2.50 & 2.21 & 2.24 & 2.34 & 2.13 & 2.16 & 2.14 & 2.24 & 2.53 \\
\hline 0.02 & 0.02 & 0.01 & 0.06 & 0.04 & 0.02 & 0.02 & 0.02 & 0.02 & 0.02 & 0.01 & 0.02 & 0.02 & 0.06 & 0.03 & 0.01 & 0.02 & 0.02 & 0.02 & 0.04 \\
\hline 0.06 & 0.06 & 0.05 & 0.08 & 0.07 & 0.07 & 0.07 & 0.07 & 0.07 & 0.07 & 0.07 & 0.07 & 0.07 & 0.06 & 0.06 & 0.06 & 0.06 & 0.06 & 0.06 & 0.15 \\
\hline 0.81 & 0.84 & 0.72 & 0.81 & 0.44 & 0.56 & 0.46 & 0.55 & 0.57 & 0.48 & 0.55 & 0.48 & 0.61 & 1.34 & 0.61 & 0.57 & 0.71 & 1.06 & 0.58 & 0.86 \\
\hline 0.11 & 0.10 & 0.06 & 0.13 & 0.09 & 0.08 & 0.09 & 0.09 & 0.09 & 0.08 & 0.08 & 0.09 & 0.11 & 0.23 & 0.13 & 0.10 & 0.10 & 0.13 & 0.08 & 0.17 \\
\hline 100.09 & 99.92 & 100.07 & 99.81 & 100.58 & 100.29 & 100.33 & 100.26 & 100.33 & 100.74 & 100.24 & 100.31 & 100.44 & 99.80 & 100.07 & 100.14 & 100.08 & 99.97 & 99.92 & 99.64 \\
\hline \multicolumn{20}{|c|}{ CIPW Norm ${ }^{a}$} \\
\hline- & - & - & - & - & - & - & - & - & - & - & - & - & - & - & - & - & - & - & - \\
\hline 0.12 & 0.12 & 0.06 & 0.36 & 0.23 & 0.12 & 0.12 & 0.12 & 0.12 & 0.12 & 0.06 & 0.12 & 0.12 & 0.36 & 0.18 & 0.06 & 0.12 & 0.12 & 0.12 & 0.24 \\
\hline 18.20 & 18.66 & 18.38 & 20.97 & 22.66 & 19.26 & 18.07 & 20.36 & 18.67 & 20.28 & 17.67 & 21.12 & 18.65 & 19.04 & 19.82 & 18.02 & 18.27 & 18.13 & 18.98 & 21.52 \\
\hline 32.88 & 33.26 & 32.82 & 31.41 & 28.06 & 30.31 & 31.74 & 31.10 & 30.09 & 27.98 & 30.67 & 28.24 & 30.87 & 33.03 & 33.64 & 34.05 & 33.62 & 34.86 & 32.23 & 30.44 \\
\hline 25.23 & 25.96 & 27.33 & 21.99 & 29.77 & 25.79 & 26.04 & 26.29 & 25.23 & 26.37 & 25.95 & 26.23 & 25.52 & 17.35 & 25.28 & 24.66 & 24.97 & 23.41 & 26.35 & 23.75 \\
\hline 13.14 & 11.56 & 12.58 & 16.86 & 3.41 & 17.18 & 14.20 & 12.29 & 17.09 & 17.64 & 17.98 & 15.83 & 14.87 & 23.96 & 9.05 & 15.53 & 12.98 & 13.07 & 11.62 & 14.44 \\
\hline 5.39 & 5.38 & 4.03 & 2.81 & 11.08 & 2.49 & 5.14 & 5.06 & 3.55 & 2.67 & 2.77 & 3.62 & 4.90 & 0.49 & 7.22 & 2.94 & 5.21 & 5.22 & 5.95 & 3.25 \\
\hline 1.65 & 1.67 & 1.65 & 2.13 & 1.80 & 1.78 & 1.69 & 1.67 & 1.84 & 1.95 & 1.82 & 1.82 & 1.88 & 1.58 & 1.60 & 1.63 & 1.58 & 1.52 & 1.67 & 2.60 \\
\hline 0.14 & 0.14 & 0.12 & 0.19 & 0.16 & 0.17 & 0.17 & 0.17 & 0.17 & 0.17 & 0.17 & 0.17 & 0.17 & 0.14 & 0.14 & 0.14 & 0.14 & 0.14 & 0.14 & 0.36 \\
\hline 0.25 & 0.23 & 0.14 & 0.30 & 0.20 & 0.18 & 0.20 & 0.20 & 0.20 & 0.18 & 0.18 & 0.20 & 0.25 & 0.53 & 0.30 & 0.23 & 0.23 & 0.30 & 0.18 & 0.39 \\
\hline
\end{tabular}

as $\mathrm{Sr}, \mathrm{Zr}, \mathrm{Hr}$, and the rare earths. This is especially well documented in the chondrite-normalized rare earth distribution patterns, which are almost chondritic or even enriched in the light rare earths (see Fig. 5B). Since the $\mathrm{Mg}$ values and the $\mathrm{Cr}$ and $\mathrm{Ni}$ concentrations indicate that the degree of fractionation of the melts from which Lithologic Units 5 and 36 were derived was comparable to that in the magmas from which all the other basalts were generated, it is likely that the starting liquids were derived from a chemically different mantle source. For the generation of the melts that produced the Lithologic Units 5 and 36 basalts, the possibility of a LIL-elementenriched ("'plume") mantle source has to be taken into consideration. Natland and Melson (1980) suggested the existence of localized pockets of less depleted mantle to explain similar basalts in and near the Siqueiros Frac- 
Table 3. (Continued).

\begin{tabular}{|c|c|c|c|c|c|c|c|c|c|c|c|c|c|c|c|c|c|c|c|c|}
\hline & \multicolumn{20}{|c|}{ Leg 70 , Hole 504B } \\
\hline & \multicolumn{20}{|c|}{ Sample } \\
\hline & 5341 & 5342 & 5343 & 5344 & 5345 & 5346 & 5347 & 5348 & 5349 & 5350 & 5351 & 5352 & 5353 & 5354 & 5355 & 5356 & 5357 & 5358 & 5359 & 5360 \\
\hline \multicolumn{21}{|c|}{ Major Elements (wt.\%) } \\
\hline $\mathrm{SiO}_{2}$ & 49.2 & 49.6 & 49.2 & 49.4 & 49.2 & 49.8 & 49.5 & 49.4 & 49.4 & 48.8 & 48.9 & 49.5 & 49.1 & 49.2 & 49.4 & 49.1 & 50.1 & 50.2 & 49.7 & 49.7 \\
\hline & 1.36 & 1.34 & 1.31 & 1.33 & 1.30 & 1.02 & 0.91 & 0.98 & 0.96 & 1.01 & 1.04 & 1.01 & 1.01 & 0.92 & 0.97 & 0.96 & 1.10 & 1.14 & 0.90 & 0.90 \\
\hline $\mathrm{Al}_{2} \mathrm{O}_{3}$ & 15.2 & 15.1 & 15.0 & 14.9 & 14.9 & 14.8 & 15.8 & 15.4 & 15.4 & 15.3 & 15.8 & 14.8 & 15.3 & 14.8 & 15.4 & 15.1 & 14.2 & 14.1 & 15.3 & 15.1 \\
\hline $\mathrm{Fe}_{2} \mathrm{O}_{3}$ & 3.69 & 3.53 & 3.80 & 3.40 & 3.66 & 2.58 & 2.65 & 3.10 & 2.48 & 3.84 & 4.20 & 4.24 & 3.22 & 3.00 & 3.23 & 3.06 & 3.60 & 3.42 & 2.91 & 3.62 \\
\hline $\mathrm{FeO}$ & 5.80 & 5.58 & 5.72 & 6.10 & 5.88 & 7.19 & 6.54 & 6.15 & 6.83 & 6.35 & 5.94 & 5.39 & 6.84 & 6.97 & 6.51 & 6.88 & 3.60 & 7.65 & 6.79 & 6.26 \\
\hline $\mathrm{MnO}$ & 0.18 & 0.18 & 0.18 & 0.19 & 0.18 & 0.17 & 0.16 & 0.18 & 0.16 & 0.18 & 0.18 & 0.17 & 0.17 & 0.17 & 0.19 & 0.17 & 0.18 & 0.18 & 0.17 & 0.16 \\
\hline $\mathrm{MgO}$ & 7.66 & 8.44 & 8.10 & 8.42 & 8.31 & 8.42 & 8.38 & 8.36 & 8.66 & 7.79 & 7.03 & 8.93 & 8.10 & 8.65 & 8.16 & 8.51 & 8.42 & 8.02 & 8.29 & 8.49 \\
\hline $\mathrm{CaO}$ & 13.2 & 12.4 & 12.9 & 12.4 & 12.7 & 12.7 & 13.0 & 12.9 & 12.7 & 13.1 & 13.6 & 12.1 & 13.0 & 12.6 & 13.0 & 12.7 & 12.0 & 11.9 & 12.8 & 12.6 \\
\hline $\mathrm{Na}_{2} \mathrm{O}$ & 2.48 & 2.45 & 2.39 & 2.73 & 2.59 & 2.25 & 2.08 & 2.22 & 2.16 & & 2.17 & 2.03 & 2.10 & 2.05 & 2.04 & 1.94 & 2.20 & 2.26 & 2.11 & 2.14 \\
\hline $\mathrm{K}_{2} \mathrm{O}$ & 0.03 & 0.04 & 0.03 & 0.04 & 0.05 & 0.02 & 0.01 & 0.02 & 0.02 & 0.01 & 0.02 & 0.01 & 0.02 & 0.01 & 0.01 & 0.01 & 0.01 & 0.01 & 0.01 & 0.01 \\
\hline $\mathrm{P}_{2} \mathrm{O}_{5}$ & 0.15 & 0.16 & 0.14 & 0.15 & 0.15 & 0.08 & 0.06 & 0.07 & 0.07 & 0.08 & 0.08 & 0.09 & 0.08 & 0.08 & 0.07 & 0.07 & 0.08 & 0.09 & 0.07 & 0.07 \\
\hline $\mathrm{H}_{2} \mathrm{O}^{+}$ & 0.64 & 0.81 & 0.82 & 0.72 & 0.79 & 0.54 & 0.57 & 0.82 & 0.88 & 1.08 & 1.02 & 1.34 & 0.85 & 0.92 & 0.87 & 0.95 & 0.65 & 0.47 & 0.62 & 0.76 \\
\hline $\mathrm{CO}_{2}$ & 0.12 & 0.16 & 0.13 & 0.13 & 0.13 & 0.07 & 0.08 & 0.14 & 0.08 & 0.12 & 0.12 & 0.22 & 0.10 & 0.09 & 0.11 & 0.09 & 0.13 & 0.09 & 0.13 & 0.13 \\
\hline Total & 99.71 & 99.79 & 99.72 & 99.91 & 99.84 & 99.64 & 99.77 & 99.74 & 99.80 & 99.72 & 100.10 & 99.83 & 99.84 & 99.53 & 99.96 & 99.54 & 99.68 & 99.53 & 99.80 & 99.91 \\
\hline \multicolumn{21}{|c|}{ CIPW Norm ${ }^{a}$} \\
\hline Q & - & - & - & - & - & - & - & - & - & - & - & - & - & - & - & - & - & - & - & - \\
\hline or & 0.18 & 0.24 & 0.18 & 0.24 & 0.30 & 0.12 & 0.06 & 0.12 & & & & & 0.12 & 0.06 & & 0.06 & 0.06 & 0.06 & 0.06 & \\
\hline ab & 21.09 & 20.82 & 20.33 & 23.17 & 22.00 & 19.13 & 17.66 & 18.86 & 18.33 & 17.52 & 18.39 & 17.25 & 17.83 & 17.46 & 17.30 & 16.52 & 18.72 & 19.25 & 17.92 & 18.16 \\
\hline & 30.41 & 30.21 & 30.27 & 28.3 & 28. & 30. & 33. & 32. & 32 . & 32.6 & & 31.38 & 32.23 & 31.35 & 32.9 & 32.6 & 28. & 28.49 & 32.36 & 31.66 \\
\hline & 27.38 & 23.88 & 26.24 & 25.57 & 26.34 & 26.01 & 24. & 24.9 & 24.23 & 25. & 26. & 21. & 25.53 & 24. & 24.8 & 24.1 & 24. & 24. & 24.48 & 24.2 \\
\hline hy & 9.21 & 14.61 & 11.63 & 7.79 & 8.16 & $\begin{array}{l}15.39 \\
15.01\end{array}$ & 15.4 & 14.03 & 14.90 & 14.40 & 11.25 & 22.42 & 14.29 & 17.09 & 16.72 & 18.30 & 21.96 & 22.22 & 17.49 & 17.48 \\
\hline ol & 5.70 & 3.97 & 5.2 & 8. & 8. & 3. & 3. & 4. & 4.8 & 4.0 & 4.27 & & 4.63 & 3.89 & 2.83 & 2.95 & 0.78 & 0.36 & 2.72 & \\
\hline il & 2.60 & 2.5 & 2.5 & 2. & 2.4 & 1. & 1. & 1. & & i. & 1.8 & i. & 1. & 1.8 & & & & & 1.72 & \\
\hline ap & 0.36 & 0.38 & & & 0.36 & 0.19 & & 0.17 & & & & 0.2 & 0.1 & 0.1 & 0.1 & 0. & 0.19 & 0.22 & 0.17 & 0.17 \\
\hline $\mathrm{cc}$ & 0.27 & 0.37 & 0.30 & 0.30 & 0.30 & 0.16 & 0.18 & 0.32 & 0.18 & 0.27 & 0.27 & 0.50 & 0.23 & 0.21 & 0.25 & 0.21 & 0.30 & 0.21 & 0.30 & 0.30 \\
\hline
\end{tabular}

Table 3. (Continued).

\begin{tabular}{|c|c|c|c|c|c|c|c|c|c|c|c|c|c|c|c|}
\hline & \multicolumn{11}{|c|}{ Leg 70 , Hole 504B } & \multirow[t]{2}{*}{$\begin{array}{c}\text { Leg 69, } \\
\text { Hole 505A }\end{array}$} & \multicolumn{3}{|c|}{ Leg 69 , Hole 505B } \\
\hline & \multicolumn{14}{|c|}{ Sample } & \\
\hline & 5361 & 5363 & 5364 & 5362 & 5365 & 5366 & 5367 & 5368 & 5369 & 5370 & 5371 & 5124 & 5125 & 5126 & 5127 \\
\hline \multicolumn{16}{|c|}{ Major Elements (wt.\%) } \\
\hline $\mathrm{SiO}_{2}$ & 49.6 & 49.5 & 49.8 & 50.0 & 49.5 & 49.6 & 49.8 & 49.6 & 49.1 & 49.3 & 50.9 & 49.5 & 50.1 & 49.4 & 49.3 \\
\hline $\mathrm{TiO}_{2}$ & 0.92 & 0.92 & 1.00 & 1.03 & 0.96 & 1.00 & 1.08 & 1.07 & 0.87 & 0.90 & 1.07 & 0.94 & 0.93 & 0.92 & 0.93 \\
\hline $\mathrm{Al}_{2} \mathrm{O}_{3}$ & 14.9 & 15.1 & 14.9 & 14.6 & 15.0 & 14.5 & 14.3 & 14.4 & 16.2 & 15.3 & 14.1 & 16.1 & 16.1 & 16.0 & 16.1 \\
\hline $\mathrm{Fe}_{2} \mathrm{O}_{3}$ & 2.45 & 2.68 & 3.18 & 2.92 & 2.96 & 3.99 & 4.21 & 3.88 & 2.89 & 3.01 & 3.35 & 2.29 & 2.61 & 2.46 & 2.34 \\
\hline $\mathrm{FeO}$ & 7.11 & 6.67 & 7.07 & 7.54 & 6.51 & 6.15 & 6.21 & 6.89 & 5.88 & 6.29 & 7.07 & 6.61 & 6.04 & 6.31 & 6.60 \\
\hline $\mathrm{MnO}$ & 0.17 & 0.19 & 0.17 & 0.17 & 0.1 & 0.19 & 0.21 & 0.22 & 0.22 & 0.17 & 0.16 & 0.1 & 0.14 & 0.17 & 0.17 \\
\hline $\mathrm{MgO}$ & 8.88 & 8.71 & 8.13 & 8.09 & 8.45 & 8.89 & 8.52 & 8.33 & 8.30 & 8.90 & 8.61 & 8.49 & 8.21 & 8.94 & 8.78 \\
\hline $\mathrm{CaO}$ & 13.0 & 13.0 & 12.4 & 12.4 & 12.9 & 12.2 & 12.1 & 12.3 & 13.2 & 12.8 & 11.9 & 13.0 & 12.8 & 12.7 & 12.9 \\
\hline $\mathrm{Na}_{2} \mathrm{O}$ & 2.20 & 2.13 & 2.30 & 2.35 & 2.48 & 2.11 & 2.12 & 2.30 & 2.12 & 2.12 & 2.15 & 2.36 & 2.29 & 2.28 & 2.24 \\
\hline $\mathrm{K}_{2} \mathrm{O}$ & & 0.01 & 0.01 & 0.01 & 0.05 & 0.01 & 0.01 & 0.01 & 0.01 & 0.01 & & & 0.11 & 0.02 & 0.05 \\
\hline $\mathrm{P}_{2} \mathrm{O}_{5}$ & 0.07 & 0.07 & 0.07 & 0.07 & 0.07 & 0.07 & 0.08 & & & & & & & & 0.07 \\
\hline $\mathrm{H}_{2} \mathrm{O}^{+}$ & 0.46 & 0.57 & 0.63 & 0.61 & 0.51 & 0.81 & 0.66 & 0.61 & 0.89 & 0.89 & 0.6 & 0.5 & 0.49 & 0.65 & 0.40 \\
\hline $\mathrm{CO}_{2}$ & 0.09 & 0.10 & 0.08 & 0.08 & 0.10 & 0.12 & 0.10 & 0.09 & 0.10 & 0.09 & 0.12 & 0.07 & 0.07 & 0.15 & 0.05 \\
\hline Total & 99.86 & 99.65 & 99.74 & 99.87 & 99.68 & 99.64 & 99.40 & 99.78 & 99.84 & 99.84 & 100.18 & 100.22 & 99.95 & 100.07 & 99.93 \\
\hline \multicolumn{16}{|c|}{ CIPW Norm ${ }^{a}$} \\
\hline Q & - & - & - & - & - & - & - & - & - & - & 0.76 & - & - & - & - \\
\hline or & 0.06 & & 0.06 & & 0.30 & 0.06 & 0.06 & & & 0.06 & & 0.29 & 0.65 & 0.12 & 0.30 \\
\hline$a b$ & 18.66 & 18.11 & 19.55 & 19.94 & 21.08 & 17.91 & 18.10 & 19.55 & 17.99 & 18.00 & 18.1 & 19.94 & 19.41 & 19.30 & 18.98 \\
\hline an & & 31.76 & & & & & & & & & & & & 33.37 & 3.78 \\
\hline di & 26.6 & 25.9 & 24. & 25. & 27. & & 24. & 25 . & 24. & 24. & & & & 22.84 & 23.93 \\
\hline hy & 12.7 & 14.4 & 16.4 & 16. & 8. & 16. & 21. & 15. & 12. & 14. & 23 & & 14. & 12.31 & 10.54 \\
\hline ol & & & & & & 7.7 & 1.0 & 4. & & & - & & 3.57 & 6.98 & 7.86 \\
\hline il & 1.7 & 1.76 & 1. & 1.9 & 1.8 & 1.91 & 2.07 & 2.04 & 1.66 & 1.72 & 2.03 & 1.78 & 1.77 & 1.75 & 1.77 \\
\hline ap & 0.17 & 0.17 & 0.17 & 0.17 & 0.17 & 0.17 & 0.19 & 0.19 & 0.1 & 0.1 & & & 0.14 & 0.17 & 0.17 \\
\hline$c c$ & 0.21 & 0.23 & 0.18 & 0.18 & 0.23 & 0.28 & 0.23 & 0.21 & 0.23 & 0.21 & 0.27 & 0.16 & 0.16 & 0.34 & 0.11 \\
\hline
\end{tabular}

ture Zone of the East Pacific Rise. As a working hypothesis we suggest that the Lithologic Units 5 and 36 basalts represent melt products generated within such pockets of more primitive mantle material.

\section{CONCLUSIONS}

The crustal section in Hole 504B can be roughly subdivided into an upper and a lower part on the basis of changes in chemistry due to alteration. The alteration solution in the upper part of the hole consists of seawa- ter at low temperatures and results in an enrichment in $\mathrm{K}$ and $\mathrm{Tl}$, a higher iron oxidation ratio, and a depletion of S in the "fresh" basalts. The alteration solutions in the lower part were less oxidative, as shown by the higher $\mathrm{S}$ contents and the lower iron oxidation ratio. Elements such as $\mathrm{K}$ and $\mathrm{Tl}$ show very low concentrations in the lower part of the hole.

Most of the basalts encountered at the Costa Rica Rift display the petrological and chemical characteristics typical of LIL-element-depleted ocean-ridge tholei- 


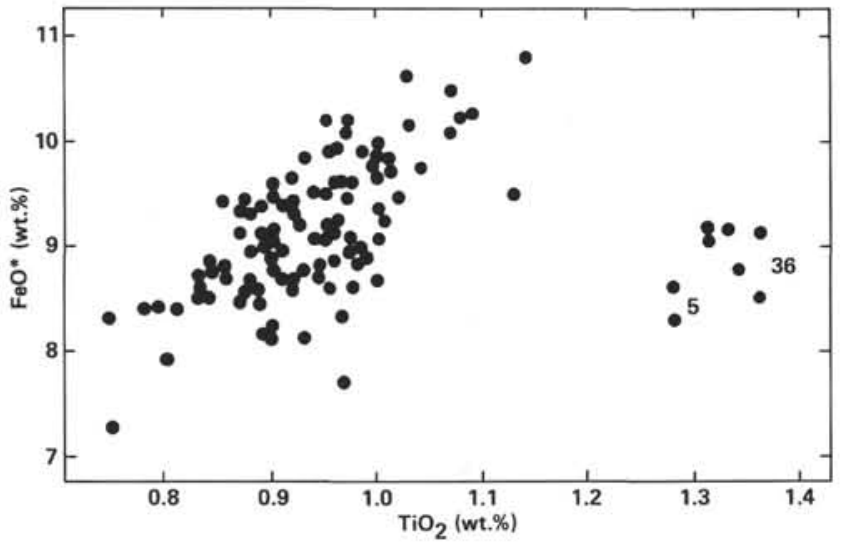

Figure 6. $\mathrm{FeO}^{*}$ plotted versus $\mathrm{TiO}_{2}$. $\mathrm{FeO}^{*}$ is total iron as $\mathrm{FeO}$.

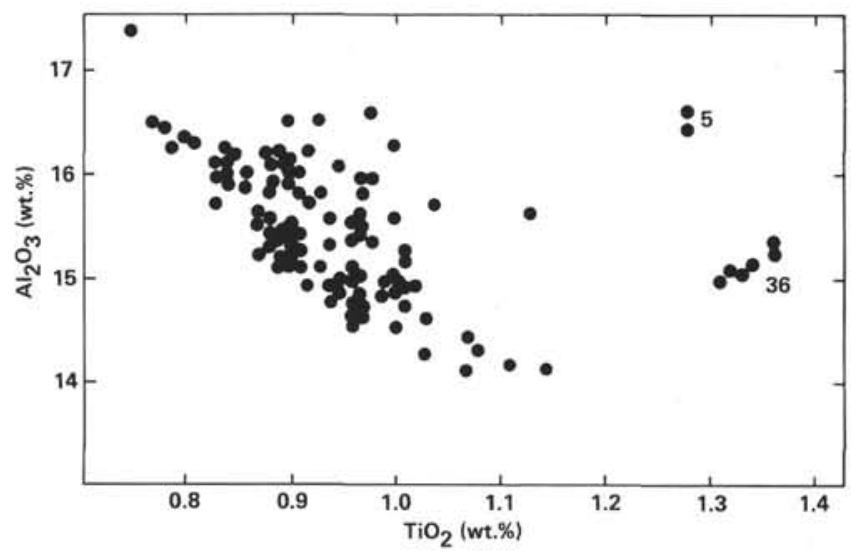

Figure 7. $\mathrm{Al}_{2} \mathrm{O}_{3}$ plotted versus $\mathrm{TiO}_{2}$.

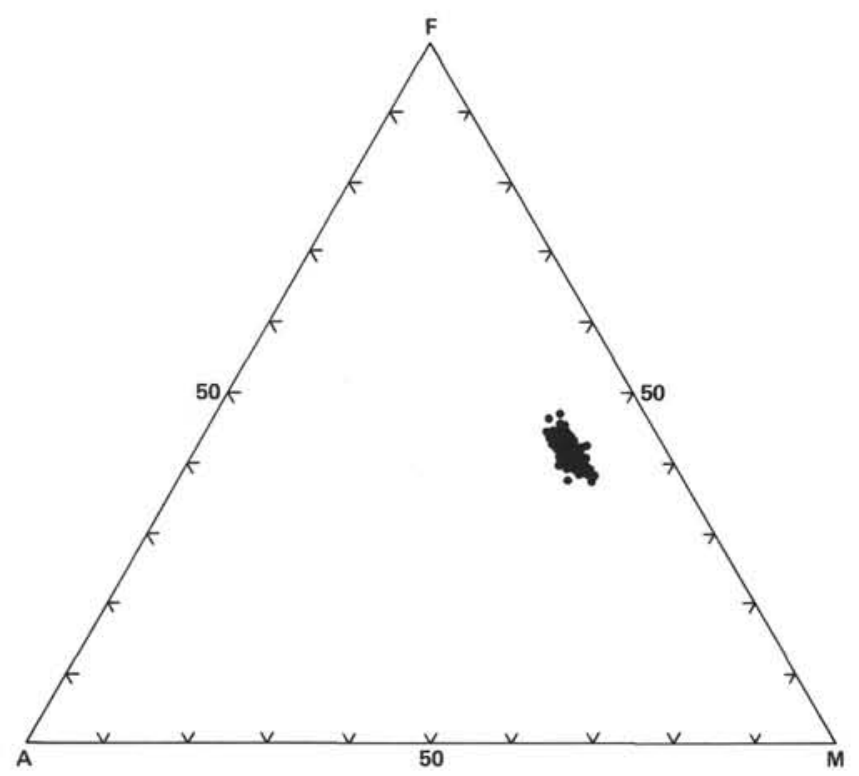

Figure 8. AFM diagram for Hole 504B.

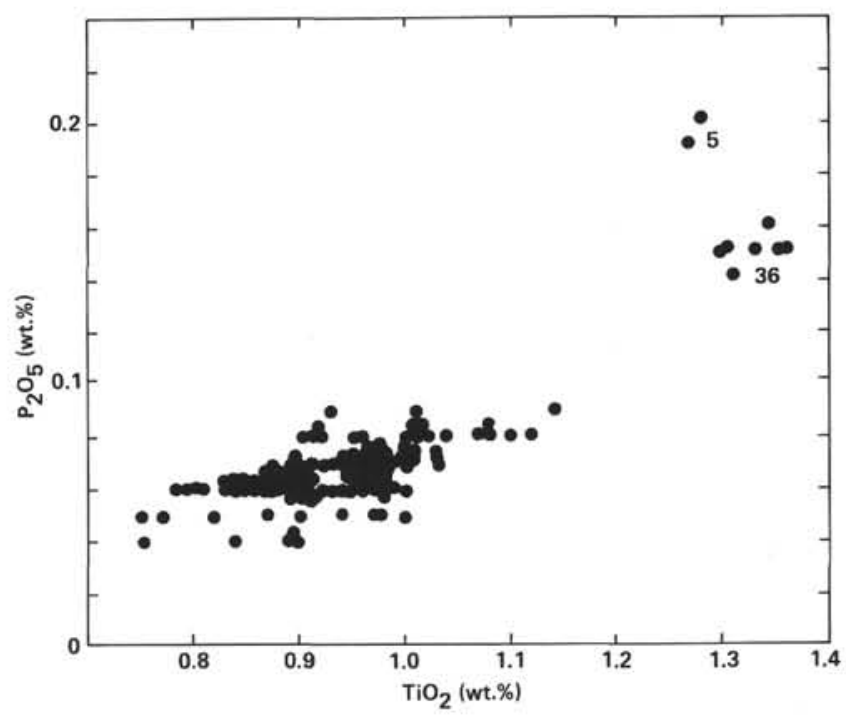

Figure 9. $\mathrm{P}_{2} \mathrm{O}_{5}$ plotted versus $\mathrm{TiO}_{2}$.

ites. They can almost all be classified as olivine tholeiites according to their normative mineralogy. No significant chemical downhole variation could be observed. These normal Costa Rica Rift basalts were probably formed by olivine-plagioclase fractionation of a magma derived from a depleted mantle source.

The basalts of Lithologic Units 5 and 36 are almost identical to the others with respect to their major element composition and their normative mineralogy. However, they are less depleted in LIL elements than the other basalts and are believed to have formed from magmas derived from localized pockets of a less depleted mantle.

\section{ACKNOWLEDGMENTS}

This investigation was supported by a grant from the Deutsche Forschungsgemeinschaft. Neutron activation analyses were carried out with equipment provided by the Bundesministerium für Forschung und Technologie. The manuscript was reviewed by J. H. Natland.

\section{REFERENCES}

Anderson, R. N., Clague, D. A., Klitgord, K. D., Marshall, M., and Nushimori, R. K., 1975. Magnetic and petrologic variations along the Galapagos Spreading Center and their relation to the Galapagos melting anomaly. Geol. Soc. Am. Bull., 86:683-694.

Byerly, G. R., Melson, W. G., and Vogt, P. R., 1976. Rhyodacites, andesites, ferro-basalts and ocean tholeiites from the Galapagos Spreading Center. Earth Planet. Sci. Lett., 30:215-221.

CRRUST, 1982. Geothermal regimes of the Costa Rica Rift, East Pacific, investigated by drilling, DSDP-IPOD Legs 68, 69 and 70 . Geol. Soc. Am. Bull., 93:862-875.

Emmermann, R., Hubberten, H.-W., and Puchelt, H., in press. Geochemistry of basalts erupted at the Galapagos Spreading Center between $85-87^{\circ}$ W. In Honnorez, J., Von Herzen, R. P., et al., Init. Repts. DSDP, 70: Washington (U.S. Govt. Printing Office).

Erzinger, J., 1981. Zur Geochemie von Selen und Thallium in magmatischen Gesteinen-mit einem Beitrag zur Analytik von Selen in geochemischen Matrizes [Ph.D. dissert.]. University of Karlsruhe, Karlsruhe, Germany.

Honnorez, J., 1980. The aging of the oceanic crust at low temperature. In Emiliani, C. (Ed.), The Sea (Vol. 7): New York (Wiley Interscience), 528-587. 
Kramar, U., and Puchelt, H., in press. Reproduciblity for INAA trace element determinations with AGV, BCR and GSP and new data for 18 geochemical reference materials. Geostandards Newslet.

Lonsdale, P., and Klitgord, K. D., 1978. Structure and tectonic history of the Eastern Panama Basin. Geol. Soc. Am. Bull., 89:981-999.

Masuda, A., 1975. Abundances of monoisotopic REE, consistent with the Leedey chondrite value. Geochem. J., 9:183-184.

McGoldrick, P. J., Keays, R. R., and Scott, B. B., 1979. Thallium: a sensitive indicator of rock/seawater interaction and of sulfur saturation of silicate melts. Geochim. Cosmochim. Acta, 43:1303-1311.

Melson, W. G., Byerly, G. R., Nelen, J. A., O'Hearn, T., Wright, T. L., and Vallier, T., 1977. A catalog of the major element chemistry

Table 4. Trace element contents, the oxidation ratio, and the $\mathrm{Mg}$ value for all investigated samples of "freshest" basalts.

\begin{tabular}{|c|c|c|c|c|c|c|c|c|c|}
\hline Sample & $\underset{(\mathrm{ppm})}{\mathrm{Ni}}$ & $\underset{(\mathrm{ppm})}{\mathrm{Zn}}$ & $\begin{array}{c}\mathrm{Y} \\
(\mathrm{ppm})\end{array}$ & $\underset{(\mathrm{ppm})}{\mathrm{Sr}}$ & $\underset{(\mathrm{ppm})}{\mathrm{Zr}}$ & $\underset{(\mathrm{ppm})}{\mathrm{S}}$ & $\underset{(\mathrm{ppb})}{T 1}$ & $\begin{array}{c}\text { Oxidation } \\
\text { Ratio }^{\mathrm{a}}\end{array}$ & $\mathrm{Mg}^{\mathrm{b}}$ \\
\hline 5101 & 64 & 81 & 30 & 76 & 61 & 1221 & - & 32 & 48.4 \\
\hline 5102 & 71 & 82 & 31 & 80 & 57 & 1197 & - & 31 & 47.7 \\
\hline 5103 & 92 & 83 & 29 & 76 & 54 & 229 & - & 40 & 48.7 \\
\hline 5104 & 102 & 90 & 28 & 81 & 55 & 1224 & - & 38 & 53.6 \\
\hline 5105 & 65 & 82 & 27 & 79 & 56 & 200 & 13 & 44 & 49.0 \\
\hline 5106 & 112 & 71 & 26 & 77 & 48 & 272 & 26 & 35 & 52.9 \\
\hline 5107 & 119 & 74 & 34 & 82 & 47 & 525 & 56 & 41 & 51.5 \\
\hline 5108 & 85 & 81 & 31 & 83 & 59 & 160 & 5 & 46 & 51.6 \\
\hline 5109 & 111 & 74 & 24 & 79 & 50 & 578 & 53 & 28 & 54.1 \\
\hline 5110 & 116 & 69 & 29 & 81 & 50 & 106 & 1 & 38 & 51.2 \\
\hline 5167 & n.d. & n.d. & n.d. & n.d. & n.d. & 762 & - & 35 & 54.6 \\
\hline 5111 & 130 & 73 & 25 & 78 & 45 & 891 & 201 & 40 & 52.1 \\
\hline 5168 & n.d. & n.d. & n.d. & n.d. & n.d. & 547 & - & 37 & 52.1 \\
\hline 5112 & 62 & 82 & 31 & 65 & 33 & 157 & 8 & 46 & 48.5 \\
\hline 5113 & 82 & 79 & 30 & 91 & 49 & 193 & 6 & 43 & 51.9 \\
\hline 5151 & n.d. & n.d. & n.d. & n.d. & n.d. & 300 & - & 44 & 52.4 \\
\hline 5152 & n.d. & n.d. & n.d. & n.d. & n.d. & 218 & - & 42 & 52.3 \\
\hline 5153 & n.d. & n.d. & n.d. & n.d. & n.d. & 154 & - & 43 & 54.3 \\
\hline 5154 & n.d. & n.d. & n.d. & n.d. & n.d. & 139 & - & 47 & 50.1 \\
\hline 5155 & n.d. & n.d. & n.d. & n.d. & n.d. & 157 & - & 56 & 49.3 \\
\hline 5156 & n.d. & n.d. & n.d. & n.d. & n.d. & 195 & - & 45 & 51.5 \\
\hline 5160 & n.d. & n.d. & n.d. & n.d. & n.d. & 172 & - & 47 & 51.0 \\
\hline 5157 & n.d. & n.d. & n.d. & n.d. & n.d. & 338 & - & 49 & 55.3 \\
\hline 5158 & n.d. & n.d. & n,d. & n.d. & n.d. & 138 & - & 38 & 55.8 \\
\hline 5159 & n.d. & n.d. & n.d. & n.d. & n.d. & 495 & - & 32 & 51.9 \\
\hline 5114 & 173 & 85 & 30 & 74 & 48 & 635 & 134 & 36 & 57.1 \\
\hline 5161 & n.d. & n.d. & n.d. & n.d. & n.d. & 75 & - & 39 & 51.6 \\
\hline 5115 & 133 & 73 & 28 & 101 & 53 & 663 & 33 & 43 & 54.9 \\
\hline 5116 & 112 & 74 & 30 & 175 & 101 & 576 & 35 & 49 & 47.7 \\
\hline 5117 & 108 & 71 & 27 & 176 & 101 & 559 & 37 & 45 & 50.5 \\
\hline 5118 & 122 & 69 & 25 & 75 & 44 & 348 & 24 & 35 & 52.6 \\
\hline 5162 & n.d. & n.d. & n.d. & n.d. & n.d. & 788 & - & 43 & 50.2 \\
\hline 5163 & n.d. & n.d. & n.d. & n.d. & n.d. & 152 & - & 50 & 50.7 \\
\hline 5164 & n.d. & n.d. & n.d. & n.d. & n.d. & 363 & - & 47 & 54.9 \\
\hline 5165 & n.d. & n.d. & n.d. & n.d. & n.d. & 668 & - & 45 & 51.9 \\
\hline 5119 & 99 & 71 & 27 & 70 & 41 & 479 & 28 & 34 & 51.9 \\
\hline 5166 & n.d. & n.d. & n.d. & n.d. & n.d. & 189 & - & 48 & 48.7 \\
\hline 5120 & 97 & 83 & 30 & 78 & 52 & 173 & 8 & 38 & 53.5 \\
\hline 5121 & 85 & 83 & 29 & 75 & 51 & 116 & 2 & 42 & 50.8 \\
\hline 5122 & 108 & 76 & 32 & 69 & 53 & 130 & 3 & 39 & 50.2 \\
\hline 5123 & 95 & 76 & 34 & 76 & 54 & 163 & 3 & 39 & 52.5 \\
\hline 5301 & 103 & 65 & 27 & 52 & 48 & 538 & - & 36 & 52.3 \\
\hline 5302 & 121 & 60 & 30 & 83 & 53 & 191 & - & 37 & 53.8 \\
\hline 5303 & 95 & 56 & 25 & 66 & 43 & 994 & 7 & 26 & 51.8 \\
\hline 5304 & 90 & 65 & 21 & 63 & 51 & 1040 & 4 & 24 & 51.0 \\
\hline 5305 & 93 & 59 & 28 & 58 & 44 & 1087 & 2 & 25 & 50.5 \\
\hline 5307 & 126 & 55 & 24 & 86 & 41 & 175 & 6 & 26 & 52.3 \\
\hline 5308 & 97 & 57 & 23 & 67 & 44 & 996 & - & 24 & 51.6 \\
\hline 5309 & 82 & 59 & 26 & 62 & 42 & 1009 & 9 & 25 & 49.7 \\
\hline 5310 & 78 & 59 & 31 & 69 & 47 & 421 & - & 32 & 51.6 \\
\hline 5311 & 107 & 48 & 27 & 71 & 36 & 980 & 2 & 25 & 54.0 \\
\hline 5312 & 131 & 51 & 29 & 62 & 42 & 880 & 4 & 23 & 55.0 \\
\hline 5313 & 125 & 48 & 22 & 65 & 36 & 920 & 2 & 23 & 56.4 \\
\hline 5314 & 113 & 53 & 26 & 67 & 37 & 820 & - & 22 & 55.8 \\
\hline 5315 & 79 & 45 & 36 & 66 & 47 & 990 & 2 & 27 & 52.1 \\
\hline 5316 & 87 & 56 & 34 & 66 & 47 & 340 & - & 35 & 54.0 \\
\hline
\end{tabular}

a Oxidation ratio is $\left(\mathrm{Fe}_{2} \mathrm{O}_{3} / \mathrm{Fe}_{2} \mathrm{O}_{3}+\mathrm{FeO}\right) \times 100$.

${ }^{b} \mathrm{Mg}$ value is $\left(\mathrm{MgO} / \mathrm{MgO}^{\circ}+0.85 \mathrm{FeO}^{*}\right) \times 100$, where $\mathrm{FeO} *$ is total iron as $\mathrm{FeO}$. of abyssal volcanic glasses. In Mason, B. (Ed.), Mineral Sciences Investigations, 1974-1975, Smithson. Contrib. Earth Sci., 19:31-60. Natland, J. H., and Melson, W. G., 1980. Compositions of basaltic glasses from the East Pacific Rise and Siqueiros Fracture Zone, near $9^{\circ}$ N. In Rosendahl, B. R., Hekinian, R., et al., Init. Repts. DSDP, 54: Washington (U.S. Govt. Printing Office), 705-723.

Puchelt, H., and Emmermann, R., in press. Petrogenetic implications from tholeiite basalt glasses from the East Pacific Rise and the Galapagos Spreading Center. Chem. Geol.

Puchelt, H. and Kramar, U., 1981. New analytical data and homogeneity of BHVO-1. Geostandards Newslet., 5:87-94.

Table 4. (Continued).

\begin{tabular}{|c|c|c|c|c|c|c|c|c|c|}
\hline Sample & $\begin{array}{c}\mathrm{Ni} \\
(\mathrm{ppm})\end{array}$ & $\underset{(\mathrm{ppm})}{\mathrm{Zn}}$ & $\begin{array}{c}\mathrm{Y} \\
(\mathrm{ppm})\end{array}$ & $\begin{array}{c}\mathrm{Sr} \\
(\mathrm{ppm})\end{array}$ & $\begin{array}{c}\mathrm{Zr} \\
(\mathrm{ppm})\end{array}$ & $\underset{(\mathrm{ppm})}{\mathrm{S}}$ & $\begin{array}{c}\mathrm{Tl} \\
\text { (ppb) }\end{array}$ & $\begin{array}{c}\text { Oxidation } \\
\text { Ratio }^{\mathrm{a}}\end{array}$ & $\mathrm{Mg}^{\mathrm{b}}$ \\
\hline 5317 & 104 & 49 & 24 & 65 & 34 & 748 & 9 & 36 & 53.7 \\
\hline 5318 & 94 & 60 & 19 & 63 & 46 & 579 & - & 29 & 51.7 \\
\hline 5319 & 96 & 63 & 18 & 66 & 35 & 619 & 3 & 33 & 52.4 \\
\hline 5320 & 105 & 60 & 29 & 64 & 43 & 657 & - & 33 & 49.8 \\
\hline 5321 & 103 & 51 & 33 & 66 & 46 & 335 & 2 & 31 & 49.1 \\
\hline 5322 & 93 & 73 & 39 & 63 & 53 & 565 & - & 31 & 48.9 \\
\hline 5323 & 87 & 56 & 28 & 67 & 49 & 232 & 1 & 28 & 51.3 \\
\hline 5325 & 70 & 67 & 31 & 58 & 40 & 808 & - & 31 & 49.5 \\
\hline 5326 & 89 & 52 & 27 & 61 & 42 & 643 & 1 & 31 & 53.3 \\
\hline 5328 & 67 & 63 & 22 & 61 & 39 & 893 & - & 34 & 50.2 \\
\hline 5329 & 62 & 68 & 27 & 60 & 48 & 452 & 2 & 32 & 49.8 \\
\hline 5330 & 47 & 80 & 27 & 57 & 48 & 737 & - & 29 & 47.4 \\
\hline 5331 & 79 & 65 & 26 & 57 & 46 & 215 & 1 & 30 & 49.6 \\
\hline 5332 & 74 & 67 & 29 & 56 & 51 & 422 & - & 31 & 49.7 \\
\hline 5333 & 81 & 66 & 28 & 61 & 49 & 175 & - & 31 & 52.8 \\
\hline 5334 & 84 & 51 & 27 & 56 & 41 & 778 & - & 45 & 54.6 \\
\hline 5335 & 91 & 57 & 29 & 57 & 38 & 552 & 10 & 33 & 53.3 \\
\hline 5336 & 100 & 56 & 25 & 69 & 35 & 460 & - & 27 & 52.6 \\
\hline 5337 & 106 & 49 & 28 & 66 & 32 & 934 & 2 & 24 & 54.1 \\
\hline 5338 & 100 & 49 & 32 & 66 & 45 & 943 & - & 31 & 56.5 \\
\hline 5339 & 93 & 53 & 31 & 70 & 44 & 1000 & 2 & 23 & 52.5 \\
\hline 5340 & 77 & 64 & 42 & 115 & 107 & 443 & - & 37 & 53.0 \\
\hline 5341 & 72 & 63 & 39 & 116 & 106 & 224 & 2 & 38 & 49.6 \\
\hline 5342 & 71 & 60 & 35 & 116 & 100 & 542 & - & 39 & 53.1 \\
\hline 5343 & 79 & 68 & 33 & 111 & 103 & 243 & 2 & 40 & 51.0 \\
\hline 5344 & 75 & 64 & 34 & 119 & 100 & 341 & - & 36 & 51.1 \\
\hline 5345 & 72 & 65 & 34 & 110 & 103 & 221 & 2 & 38 & 51.6 \\
\hline 5346 & 86 & 63 & 27 & 77 & 61 & 927 & - & 26 & 49.6 \\
\hline 5347 & 80 & 54 & 24 & 63 & 47 & 890 & 2 & 31 & 52.4 \\
\hline 5348 & 95 & 53 & 25 & 83 & 61 & 494 & - & 33 & 52.3 \\
\hline 5349 & 97 & 56 & 25 & 78 & 54 & 1022 & 3 & 27 & 52.9 \\
\hline 5350 & 115 & 67 & 26 & 59 & 50 & 808 & - & 38 & 48.2 \\
\hline 5351 & 109 & 66 & 23 & 56 & 52 & 731 & 3 & 41 & 46.0 \\
\hline 5352 & 94 & 68 & 27 & 57 & 47 & 460 & - & 44 & 53.2 \\
\hline 5353 & 116 & 63 & 32 & 58 & 48 & 969 & 6 & 32 & 49.4 \\
\hline 5354 & 103 & 63 & 32 & 60 & 44 & 955 & - & 30 & 51.0 \\
\hline 5355 & 125 & 60 & 31 & 61 & 43 & 395 & 6 & 33 & 50.5 \\
\hline 5356 & 127 & 64 & 37 & 63 & 45 & 648 & - & 31 & 50.8 \\
\hline 5357 & 68 & 76 & 36 & 66 & 47 & 424 & 5 & 34 & 49.1 \\
\hline 5358 & 56 & 70 & 35 & 69 & 56 & 988 & - & 31 & 46.7 \\
\hline 5359 & 81 & 60 & 24 & 62 & 45 & 210 & 2 & 30 & 50.9 \\
\hline 5360 & 83 & 66 & 31 & 63 & 41 & 376 & - & 37 & 51.2 \\
\hline 5361 & 92 & 61 & 26 & 74 & 47 & 419 & 5 & 25 & 47.3 \\
\hline 5363 & 90 & 63 & 21 & 77 & 48 & 325 & 3 & 28 & 52.9 \\
\hline 5364 & 86 & 68 & 36 & 67 & 52 & 1067 & - & 31 & 49.0 \\
\hline 5362 & 64 & 66 & 25 & 65 & 49 & 1043 & - & 28 & 48.3 \\
\hline 5365 & 98 & 59 & 35 & 76 & 45 & 572 & 6 & 31 & 51.9 \\
\hline 5366 & 94 & 71 & 34 & 66 & 44 & 772 & & 31 & 51.7 \\
\hline 5367 & 64 & 65 & 25 & 70 & 49 & 843 & 1 & 39 & 49.9 \\
\hline 5368 & 71 & 70 & 26 & 68 & 43 & 411 & & 39 & 48.5 \\
\hline 5369 & 120 & 55 & 22 & 73 & 38 & 768 & & 32 & 53.5 \\
\hline 5370 & 147 & 55 & 31 & 72 & 39 & 1066 & & 32 & 53.7 \\
\hline 5124 & 122 & 68 & 25 & 88 & 57 & 669 & & 26 & 53.5 \\
\hline 5125 & 132 & 65 & 25 & 84 & 66 & 780 & & 30 & 53.5 \\
\hline 5126 & 133 & 70 & 26 & 84 & 55 & 971 & & 28 & 55.2 \\
\hline 5127 & 137 & 74 & 31 & 85 & 61 & 509 & & 26 & 54.3 \\
\hline
\end{tabular}


Table 5. REE and additional trace element contents of selected samples.

\begin{tabular}{|c|c|c|c|c|c|c|c|c|c|c|c|c|c|c|}
\hline \multirow{2}{*}{$\frac{\text { Hole }}{\text { Sample }}$} & \multicolumn{3}{|c|}{$504 \mathrm{~A}$} & \multirow[b]{2}{*}{5105} & \multirow[b]{2}{*}{5107} & \multirow[b]{2}{*}{5113} & \multirow[b]{2}{*}{5116} & \multirow[b]{2}{*}{5118} & \multicolumn{3}{|c|}{$504 \mathrm{~B}$} & \multirow[b]{2}{*}{5304} & \multirow[b]{2}{*}{5309} & \multirow[b]{2}{*}{5310} \\
\hline & & 5101 & 5104 & & & & & & 5120 & 5122 & 5301 & & & \\
\hline & $\mathrm{Sc}$ & 48 & 51 & 48 & 42 & 43 & 38 & 40 & 48 & 44 & 43 & 47 & 46 & 48 \\
\hline & $\mathrm{Cr}$ & 236 & 235 & 206 & 428 & 336 & 316 & 386 & 289 & 302 & 291 & 377 & 351 & 363 \\
\hline & Co & 45 & 54 & 48 & 47 & 44 & 41 & 50 & 48 & 46 & 54 & 44 & 48 & 48 \\
\hline & $\mathrm{La}$ & 1.1 & 1.3 & 3.8 & 1.6 & 1.2 & 8.6 & 1.1 & 1.4 & 0.90 & 1.3 & 1.2 & 1.1 & 1.1 \\
\hline & $\mathrm{Ce}$ & 4.8 & 5.9 & 12.3 & 3.5 & 4.7 & 15.8 & 3.4 & 3.6 & 4.5 & 2.6 & 5.4 & 3.5 & 3.1 \\
\hline & $\mathrm{Nd}$ & 4.8 & 6.9 & 6.7 & 5.1 & 4.1 & 11.0 & 4.3 & 6.4 & 5.1 & 5.0 & 4.1 & 4.1 & 4.3 \\
\hline & $\mathrm{Sm}$ & 2.3 & 2.4 & 2.6 & 2.3 & 2.3 & 3.4 & 2.0 & 2.4 & 2.3 & 2.2 & 2.0 & 2.2 & 2.1 \\
\hline \multirow[t]{8}{*}{ Element } & $\mathrm{Eu}$ & 0.89 & 0.95 & 0.92 & 0.77 & 0.83 & 1.1 & 0.75 & 0.88 & 0.86 & 0.77 & 0.81 & 0.77 & 0.73 \\
\hline & Gd & 4.7 & 4.6 & 4.6 & 3.7 & 3.6 & 5.1 & 3.4 & 4.0 & 4.4 & 5.0 & 3.6 & 3.9 & 3.7 \\
\hline & $\mathrm{Tb}$ & 0.72 & 0.76 & 0.77 & 0.65 & 0.65 & 0.71 & 0.52 & 0.65 & 0.61 & 0.61 & 0.65 & 0.58 & 0.59 \\
\hline & Ho & 0.80 & 1.2 & 0.99 & 1.3 & 1.0 & 0.93 & 0.97 & 1.0 & 0.75 & 1.1 & 0.91 & 1.1 & 0.96 \\
\hline & $\mathrm{Yb}$ & 3.3 & 3.6 & 3.2 & 2.9 & 2.8 & 2.9 & 2.7 & 3.0 & 3.0 & 2.9 & 2.9 & 2.7 & 3.0 \\
\hline & $\mathrm{Lu}$ & 0.47 & 0.54 & 0.46 & 0.40 & 0.37 & 0.39 & 0.38 & 0.42 & 0.45 & 0.42 & 0.46 & 0.39 & 0.41 \\
\hline & Hf & 1.8 & 1.8 & 1.5 & 1.6 & 1.5 & 2.2 & 1.2 & 1.5 & 1.4 & 1.5 & 1.3 & 1.2 & 1.2 \\
\hline & $\mathrm{Ta}$ & 0.06 & 1.1 & 0.11 & 0.16 & 0.08 & 0.73 & 0.08 & 0.04 & 0.23 & - & 0.02 & - & - \\
\hline
\end{tabular}

Table 5. (Continued).

\begin{tabular}{|c|c|c|c|c|c|c|c|c|c|c|c|c|c|c|}
\hline & \multicolumn{11}{|c|}{ 504B } & \multirow{2}{*}{$\frac{505 \mathrm{~A}}{5124}$} & \multicolumn{2}{|c|}{$505 \mathrm{~B}$} \\
\hline & 5312 & 5318 & 5322 & 5325 & 5331 & 5335 & 5340 & 5349 & 5356 & 5364 & 5370 & & 5125 & 5127 \\
\hline $\mathrm{Sc}$ & 40 & 45 & 48 & 43 & 46 & 44 & 49 & 41 & 42 & 45 & 42 & 41 & 41 & 44 \\
\hline $\mathrm{Cr}$ & 462 & 343 & 181 & 163 & 149 & 261 & 262 & 334 & 288 & 232 & 349 & 456 & 454 & 484 \\
\hline Co & 41 & 47 & 52 & 47 & 50 & 46 & 47 & 47 & 48 & 48 & 48 & 41 & 42 & 45 \\
\hline $\mathrm{La}$ & 0.78 & 1.1 & 1.4 & 1.2 & 1.6 & - & 3.9 & 1.4 & 1.3 & 1.3 & 1.4 & 1.4 & 2.1 & 1.3 \\
\hline $\mathrm{Ce}$ & 4.1 & 4.0 & 6.2 & 4.3 & 3.4 & 2.6 & 10.6 & 4.2 & 3.5 & 5.6 & 3.7 & 4.7 & 5.9 & 5.8 \\
\hline $\mathrm{Nd}$ & 3.3 & 4.5 & 6.9 & 5.6 & 5.0 & 4.8 & 9.9 & 6.3 & 5.7 & 5.5 & 3.7 & 5.3 & 4.5 & 5.0 \\
\hline $\mathrm{Sm}$ & 1.7 & 2.1 & 2.8 & 2.2 & 2.3 & 2.1 & 3.7 & 2.4 & 2.4 & 2.5 & 2.2 & 2.1 & 2.1 & 2.3 \\
\hline Eu & 0.72 & 0.73 & 0.96 & 0.80 & 0.83 & 0.74 & 1.3 & 0.82 & 0.79 & 0.87 & 0.77 & 0.88 & 0.82 & 0.82 \\
\hline Gd & 2.7 & 4.0 & 6.0 & 3.7 & 3.9 & 3.9 & 5.7 & 3.5 & 3.7 & 3.6 & 3.6 & 3.5 & 3.5 & 3.5 \\
\hline $\mathrm{Tb}$ & 0.52 & 0.64 & 0.72 & 0.61 & 0.67 & 0.60 & 0.87 & 0.64 & 0.62 & 0.65 & 0.55 & 0.58 & 0.51 & 0.65 \\
\hline Ho & 0.76 & 1.1 & 1.2 & 0.96 & 0.85 & 0.91 & 1.2 & 1.1 & 0.92 & 1.0 & 1.0 & 0.82 & 0.94 & 0.83 \\
\hline $\mathrm{Yb}$ & 2.5 & 2.8 & 3.5 & 3.2 & 3.1 & 2.7 & 3.7 & 2.7 & 2.9 & 3.2 & 2.7 & 2.8 & 2.8 & 3.0 \\
\hline $\mathrm{Lu}$ & 0.37 & 0.41 & 0.49 & 0.41 & 0.45 & 0.36 & 0.55 & 0.43 & 0.46 & 0.41 & 0.46 & 0.39 & 0.42 & 0.40 \\
\hline Hf & 1.2 & 1.2 & 1.8 & 1.5 & 1.6 & 1.2 & 2.6 & 1.7 & 1.6 & 1.6 & 1.3 & 1.6 & 1.5 & 1.4 \\
\hline $\mathrm{Ta}$ & 0.02 & - & - & - & 0.03 & - & 0.13 & 0.04 & - & - & - & 0.07 & 0.09 & 0.14 \\
\hline
\end{tabular}

